\title{
Mechanisms of action and in vivo antibacterial efficacy assessment of five novel hybrid peptides derived from Indolicidin and Ranalexin against Streptococcus pneumoniae
}

\author{
Hassan Mahmood Jindal ${ }^{1}$, Keivan Zandi ${ }^{2}$, Kien Chai Ong ${ }^{3}$, Rukumani Devi Velayuthan ${ }^{1}$, Sara Maisha Rasid \\ , Chandramathi Samudi Raju ${ }^{1}$, Shamala Devi Sekaran ${ }^{\text {Corresp. } 1}$ \\ ${ }^{1}$ Department of Medical Microbiology, Department of Microbiology, Faculty of Medicine, University of Malaya, Kuala Lumpur, Malaysia \\ 2 Department of Pediatrics, School of Medicine, Emory University, Atlanta, United States \\ 3 Department of Biomedical Science, University of Malaya, Kuala Lumpur, Malaysia \\ Corresponding Author: Shamala Devi Sekaran \\ Email address: shamala@um.edu.my
}

Background. Antimicrobial peptides (AMPs) are of great potential as novel antibiotics for the treatment of broad spectrum of pathogenic microorganisms including resistant bacteria. In this study, the mechanisms of action and the therapeutic efficacy of the hybrid peptides were examined.

Methods. TEM, SEM and ATP efflux assay were used to evaluate the effect of hybrid peptides on the integrity of the pneumococcal cell wall/membrane. DNA retardation assay was assessed to measure the impact of hybrid peptides on the migration of genomic DNA through the agarose gel. In vitro synergistic effect was checked using the chequerboard assay. ICR male mice were used to evaluate the in vivo toxicity and antibacterial activity of the hybrid peptides in a standalone form and in combination with ceftriaxone.

Results. The results obtained from TEM and SEM indicated that the hybrid peptides caused significant morphological alterations in Streptococcus pneumoniae and disrupting the integrity of the cell wall/membrane. The rapid release of ATP from pneumococcal cells after one hour of incubation proposing that the antibacterial action for the hybrid peptides is based on membrane permeabilization and damage. The DNA retardation assay revealed that at $62.5 \mu \mathrm{g} / \mathrm{ml}$ all the hybrid peptides were capable of binding and preventing the pneumococcal genomic DNA from migrating through the agarose gel. In vitro synergy was observed when pneumococcal cells treated with combinations of hybrid peptides with each other and with conventional drugs erythromycin and ceftriaxone. The in vivo therapeutic efficacy results revealed that the hybrid peptide RN7-IN8 at $20 \mathrm{mg} / \mathrm{kg}$ could improve the survival rate of pneumococcal bacteremia infected mice, as $50 \%$ of the infected mice were survived up to 7 days post-infection. In vivo antibacterial efficacy of the hybrid peptide RN7-IN8 was signficantly improved when combined with the standard antibiotic ceftriaxone at $(20 \mathrm{mg} / \mathrm{kg}+20 \mathrm{mg} / \mathrm{kg})$ as $100 \%$ of the infected mice survived up to seven days post-infection.

Discussion. Our results suggest that attacking and breaching the cell wall/membrane is most probably the principal mechanism for the hybrid peptides. In addition, the hybrid peptides could possess another mechanism of action by inhibiting intracellular functions such as DNA synthesis. AMPs could play a great role in combating antibiotic resistance as they can reduce the therapeutic concentrations of standard drugs. 
1 Mechanisms of action and in vivo antibacterial efficacy assessment of five

4

5

6 7

\section{novel hybrid peptides derived from Indolicidin and Ranalexin against}

Streptococcus pneumoniae

Authors: Hassan Mahmood Jindal ${ }^{1}$, Keivan Zandi², Kein Chai Ong 3 , Rukumani Devi Velayuthan ${ }^{1}$, Sarah Maisha Rasid ${ }^{1}$, Chandramathi Samudi Raju ${ }^{1}$, and Shamala Devi Sekaran ${ }^{*}$

\section{Affiliations:}

${ }^{1}$ Department of Medical Microbiology, Faculty of Medicine, University of Malaya, 50603 Kuala Lumpur, Malaysia.

${ }^{2}$ Department of Pediatrics, School of Medicine, Emory University, 201 Dowman Dr, Atlanta, GA 30322, USA.

${ }^{3}$ Department of Biomedical Science, Faculty of Medicine, University of Malaya, 50603 Kuala Lumpur, Malaysia.

Corresponding Author: *Prof. Dr. Shamala Devi Sekaran

E-mail:shamalamy@yahoo.com 


\section{Abstract}

Background. Antimicrobial peptides (AMPs) are of great potential as novel antibiotics, for the treatment of a broad spectrum of pathogenic microorganisms including resistant bacteria. In this study, the mechanisms of action and the in vivo antibacterial efficacy of the hybrid peptides were examined.

Methods. TEM, SEM and ATP efflux assay were used to evaluate the effect of hybrid peptides on the integrity of the pneumococcal cell wall/membrane. DNA retardation assay was used to measure the impact of hybrid peptides on the migration of genomic DNA through the agarose gel. In vitro synergistic effect was checked using the checkerboard assay. ICR male mice were used to evaluate the in vivo toxicity and antibacterial activity of the hybrid peptides, in a standalone form and in combination with ceftriaxone.

Results. The results obtained from TEM and SEM indicated that the hybrid peptides caused significant morphological alterations in Streptococcus pneumoniae, disrupting the integrity of the cell wall/membrane. The rapid release of ATP from pneumococcal cells after one hour of

47 incubation proposes that the antibacterial action for the hybrid peptides is based on membrane permeabilization and damage. The DNA retardation assay revealed that at $62.5 \mu \mathrm{g} / \mathrm{ml}$, all the hybrid peptides were capable of binding and preventing the pneumococcal genomic DNA from migrating through the agarose gel. In vitro synergy was observed, when pneumococcal cells were treated with combinations of hybrid peptides with each other and with conventional drugs

52 erythromycin and ceftriaxone. The in vivo therapeutic efficacy results revealed that the hybrid peptide RN7-IN8 at 20mg/kg could improve the survival rate of pneumococcal bacteremia infected 
54 mice, as $50 \%$ of the infected mice survived up to 7 days, post-infection. in vivo antibacterial 55 efficacy of the hybrid peptide RN7-IN8 was signficantly improved, when combined with the 56 standard antibiotic ceftriaxone at $(20 \mathrm{mg} / \mathrm{kg}+20 \mathrm{mg} / \mathrm{kg})$, as $100 \%$ of the infected mice survived up 57 to seven days, post-infection.

58

Discussion. Our results suggest that attacking and breaching the cell wall/membrane is most probably the principal mechanism for the hybrid peptides. In addition, the hybrid peptides could possess another mechanism of action, by inhibiting intracellular functions such as DNA synthesis. The ability of the hybrid peptides to act synergistically with standard antibiotics, proposes that our novel AMPs could play a great role in combating antibiotic resistance, as they can reduce the therapeutic concentrations of standard drugs. 2004; Cao et al., 2007). This bacterial pathogen is capable of causing both invasive and noninvasive diseases (Moschioni et al., 2012). Globally, this pathogen is responsible for 1.6 million deaths each year, of which 0.7 to 1 million are children below five years, especially in Asian and African countries (O’Brien et al., 2009; Bravo, 2009). Since the last three decades, there has been an enormous increase in the incidence of antibiotic-resistant pneumococci, due to the extensive use of inappropriate antimicrobials (Zhou et al., 2012). Although Pneumococcal conjugate vaccine PCV served as a great tool against antibiotic resistance by S. pneumoniae and helped reduce the frequency of vaccine serotypes, there has been a considerable rise in the disease induced by non- 
77 vaccine serotypes (Reynolds et al., 2014). Hence, newer classes of antibacterial agents to overcome this serious issue are a top priority worldwide.

One of the advantageous alternatives to today's antibiotics is antimicrobial peptides (AMPs) (Deslouches et al., 2013; Sánchez-Vásquez et al., 2013). AMPs are synthesized by almost all living beings as the first line of defense in their immune system against microbial infection. Many aspects favor AMPs over traditional antibiotics: a broad range of antimicrobial activity against pathogenic micro-organisms (including viruses, parasites, bacteria, and fungi), microbial pathogens are less efficient in developing resistance against AMPs, as killing take place in a short contact time and AMPs can act in a synergistic manner with traditional antibiotics (Yeaman \& Yount, 2003; Torcato et al., 2013; Xi et al., 2013). In our earlier study, we had designed 13 novel antimicrobial peptides, based on two naturally occurring templates, indolicidin and ranalexin (Jindal et al., 2015). Of these, five hybrid peptides (RN7-IN10, RN7-IN9, RN7-IN8, RN7-IN7 and RN7-IN6) presented the most potent antimicrobial activity against 30 pneumococcal clinical isolates. The MICs of RN7-IN10, RN7-IN9, RN7-IN8 and RN7-IN6 ranged from 7.81 to $15.62 \mu \mathrm{g} / \mathrm{ml}$ for each peptide, while the MIC of RN7-IN7 was $62.5 \mu \mathrm{g} / \mathrm{ml}$. Also, none of the hybrid peptides revealed any cytotoxic effects against human cells at their MIC levels. RN7-IN10 peptide was designed by fusing the first seven amino acids at the N-terminus (FLGGLIK) of ranalexin with the $4^{\text {th }}$ to $13^{\text {th }}$ residual fragment (WKWPWWPWRR) of indolicidin. Likewise, RN7-IN9, RN7-IN8, RN7-IN7 and RN7-IN6 were also designed by trimming the first seven amino acid residues of ranalexin and fusing it with $5^{\text {th }}$ to $13^{\text {th }}, 6^{\text {th }}$ to $13^{\text {th }}, 7^{\text {th }}$ to $13^{\text {th }}$ and $8^{\text {th }}$ to $13^{\text {th }}$ residual fragments of indolicidin (Jindal et al., 2015) in order to preserve the biological activity of both segments in the newly designed hybrid peptides (Table 1 illustrate the sequences and physicochemical properties of all five hybrid peptides). In this study, we describe the mechanisms 
100 of action, the in vitro synergism effect and the in vivo antibacterial efficacy of the hybrid peptides

101 against Streptococcus pneumoniae.

102

103

\section{Materials and Methods}

104

105

106

107

108

109

110

111

112

113

114

115

116

117

118

119

120

121

122

\section{Bacterial culture and assay medium}

S. pneumoniae clinical strains used in this study were obtained from University of Malaya Medical Centre (UMMC). Columbia agar with 5\% sheep blood was used to culture the bacteria. Mueller-Hinton broth (MHB) was used for synergism assay and cationally adjusted as described in the guidelines of Clinical and Laboratory Standard Institute (2012).

\section{Transmission electron microscopy (TEM)}

Bacteria were prepared for TEM according to the guidelines of the Electron Microscopy Unit at the Faculty of Medicine, University of Malaya. S. pneumoniae cultures were grown overnight on Columbia agar with 5\% sheep blood and suspended in cationally adjusted MuellerHinton broth $(\mathrm{CAMHB})$ at $10^{8} \mathrm{CFU} / \mathrm{ml}$. Pneumococcal suspensions were incubated with hybrid peptides RN7-IN10, RN7-IN9, RN7-IN8 and RN7-IN6 at $125 \mu \mathrm{g} / \mathrm{ml}$ and with RN7-IN7 at 500 $\mu \mathrm{g} / \mathrm{ml}(8 \times$ of their respective $\mathrm{MIC})$ in a $1.5 \mathrm{ml}$ eppendorf tube for $1 \mathrm{~h}$ at $37^{\circ} \mathrm{C}$ under $5 \% \mathrm{CO}_{2}$. Cells in cationally adjusted Mueller-Hinton broth (CAMHB) were used as an untreated control. After an hour of incubation, the pneumococcal cells were centrifuged to discard the medium, washed thrice with $10 \mathrm{mM}$ phosphate buffer saline at $\mathrm{pH} 7.3$ and fixed overnight in $4 \%$ (v/v) glutaraldehyde. All samples were washed twice with cacodylate buffer, incubated for $2 \mathrm{~h}$ in osmium tetroxide buffer $\left(\mathrm{OsO}_{4}\right.$ 1: 1 cacodylate), washed twice with cacodylate buffer and then incubated overnight in cacodylate buffer. All the samples were washed with distilled water twice 
123 and incubated for 10 min with uranyl acetate. After this, all samples were then washed twice with

124 distilled water and dehydrated in an ascending series of ethanol: 35\% (10 min), 50\% (10 min), $12570 \%(10 \mathrm{~min}), 95 \%$ (15 $\mathrm{min})$, and thrice in 100\% ethanol (15 min). After dehydration, Samples

126 were incubated with propylene oxide $(15 \mathrm{~min})$, propylene oxide 1:1 Epon $(1 \mathrm{~h})$, propylene oxide

127 1:3 Epon (2 h) and finally incubated overnight with Epon. All the samples were embedded in agar 128100 resin at $37^{\circ} \mathrm{C}$ for $5 \mathrm{hr}$ and maintained at $60^{\circ} \mathrm{C}$ until viewing. Reichert Ultramicrotome copper 129 grids $3.05 \mathrm{~mm}$ (300 square mesh) (Agar Scientific) were used to prepare Ultrathin sections. 130 Ethanol-based uranyl acetate and lead citrate were used to stain the samples for 5 min. 131 Transmission electron microscope (Leo Libra 120) was used to capture the images.

133 Scanning electron microscopy (SEM)

S. pneumoniae with a starting inoculum of $1 \times 10^{8} \mathrm{CFU} / \mathrm{ml}$ in CAMHB medium, was treated with hybrid peptides RN7-IN10, RN7-IN9, RN7-IN8 and RN7-IN6 at $125 \mu \mathrm{g} / \mathrm{ml}$ and with RN7IN7 at $500 \mu \mathrm{g} / \mathrm{ml}$ of respective peptides and incubated for $1 \mathrm{~h}$ at $37{ }^{\circ} \mathrm{C}$ for under $5 \% \mathrm{CO}_{2}$. After incubation, $20 \mu \mathrm{l}$ of the untreated and treated cell suspensions were transferred onto membrane filters and processed as described by the standard guidelines provided by Electron Microscopy Unit, Faculty of Medicine, University of Malaya. Briefly, the bacterial samples were fixed overnight with $4 \%$ glutaraldehyde at $4{ }^{\circ} \mathrm{C}$ and then washed twice with sodium cacodylate buffer

141 for $10 \mathrm{~min}$ each. In the second fixation, $1 \%$ osmium tetroxide was used to fix the samples for $1 \mathrm{~h}$ 142 at $4{ }^{\circ} \mathrm{C}$ and then washed twice with distilled water for $10 \mathrm{~min}$ each. All the samples were then 143 dehydrated through a serially graded ethanol $(30 \%, 50 \%, 70 \%, 80 \%, 90 \%, 95 \%$ and twice in $144100 \%)$ for $15 \mathrm{~min}$ each, followed by dehydration in ethanol:acetone mixtures $(3: 1,1: 1$ and $1: 3)$ for $14515 \mathrm{~min}$ each and three rounds of pure acetone for 20 min each. The samples were then dried for 1 
$146 \mathrm{~h}$ and kept in a desiccator before the examination. The samples were then mounted on stubs, coated 147 with gold in sputter coater and viewed under the FEI-Quanta 650 Scanning Electron Microscope.

\section{ATP efflux assay}

The amount of ATP released from pneumococcal cells incubated with hybrid peptides was measured as described previously, with a slight modification (Tanida et al., 2006). The ATP determination kit (Molecular Probes, USA) was used to measure the amount of ATP released based on the luciferin/luciferase method according to the manufacturer's instructions. Briefly, $S$. pneumoniae were grown overnight on Columbia agar with 5\% sheep blood. Bacterial suspensions were spectrophotometrically adjusted to $\left(1 \times 10^{7} \mathrm{CFU} / \mathrm{ml}\right)$ and incubated with hybrid peptides RN7-IN10, RN7-IN9, RN7-IN8 and RN7-IN6 at $125 \mu \mathrm{g} / \mathrm{ml}$ and with RN7-IN7 at $500 \mu \mathrm{g} / \mathrm{ml}$. The amount of ATP released form the pneumococcal cells were measured at three time points 1,2 and $3 \mathrm{~h}$. The samples were then centrifuged at $5000 \mathrm{rpm}$ for $5 \mathrm{~min}$, and ATP efflux was subsequently estimated using an ATP standard curve. Values were obtained from three independent experiments. Ceftriaxone and erythromycin were used as positive controls.

\section{Gel retardation assay}

This assay was carried out as described previously, with minor modifications (Li et al., 2013). S. pneumoniae were grown overnight on Columbia agar with 5\% sheep blood. A few bacterial colonies were transferred into a $1.5 \mathrm{ml}$ eppendorf tube containing phosphate buffered saline (PBS). The bacterial cells were centrifuged, PBS was discarded and $50 \mu 1$ of TE buffer 
169 containing $0.08 \mathrm{~g} / \mathrm{ml}$ of lysozyme and $150 \mathrm{U} / \mathrm{ml}$ of mutanolysin was added to the cells. Genomic

170 DNA was isolated from pneumococcal cells using DNeasy Blood \& Tissue Kit (Qiagen),

171 following the manufacturer's giudlines. The optical density ratio of $260 \mathrm{~nm}$ and $280 \mathrm{~nm}$

$172\left(\mathrm{OD}_{260} / \mathrm{OD}_{280}=1.83\right)$ was used to measure the purity of the DNA. Genomic DNA (250 ng) was

173 incubated with hybrid peptides at various concentrations $(0.24-500 \mu \mathrm{g} / \mathrm{ml})$ in $12 \mu \mathrm{l}$ at room

174 temperature for $10 \mathrm{~min} .2 \mu \mathrm{l}$ of loading buffer were added to the mixture and the migration of DNA

175 through $1 \%$ agarose gel was evaluated by electrophoresis in $1 \times$ Tris borate-EDTA buffer (45 mM

176 Tris-borate and $1 \mathrm{mM}$ EDTA at $\mathrm{pH} \mathrm{8.0)}$ and spotted by the fluorescence of gel stain (Gel Red,

177 BIOTIUM). The natural peptide indolicidin was used as positive controls, ceftriaxone and

178 erythromycin were used as negative controls.

\section{Synergistic effect}

Pneumococcal cells were cultured overnight using Columbia agar with 5\% sheep blood at $37{ }^{\circ} \mathrm{C}$ under $5 \% \mathrm{CO}_{2}$, resuspended in cation-supplemented Mueller-Hinton broth and adjusted to $5 \times 10^{5} \mathrm{CFU} / \mathrm{ml}$, following CLSI guidelines. Combinations of hybrid AMPs with each other and with standard drugs (ceftriaxone and erythromycin) were assessed for their synergistic effects by the checkerboard titration method described previously, with minor modification (Bajaksouzian et al., 1996). Briefly, $50 \mu 1$ of eight serial two-fold dilutions of drug B starting at $4 \times \mathrm{MIC}$ were added to each column of the plate followed by $50 \mu \mathrm{l}$ of a fixed $0.25 \times \mathrm{MIC}$ of drug A, this yielded 8 peptide-peptide combinations at different ratios. $100 \mu \mathrm{l}$ of bacterial suspension $\left(5 \times 10^{5} \mathrm{CFU} / \mathrm{ml}\right)$ were then added to each well and the plates were incubated for $24 \mathrm{~h}$ at $37{ }^{\circ} \mathrm{C}$ under $5 \% \mathrm{CO}_{2}$. The fractional inhibitory concentration (FIC) index of each combination was calculated according to the following formula: 
192

193

195

196

197

198

199

200

201

202

203

204

205

206

207

208

209

210

211

212

213

214

215

216

\author{
FICI \\ MIC of drug A in combination \\ MIC of drug A alone \\ $+\frac{\text { MIC of drug B in combination }}{\text { MIC of drug B alone }}=$
}

MIC A in combination and MIC B in combination represent the MICs of drug A and B tested in combination. MIC A alone and MIC B alone represent the MICs of drug A and B in standalone.

FIC index values were interpreted as follows: Two drugs have synergy if FIC $\leq 0.5$, additive or indifference if $0.5<\mathrm{FIC} \leq 4.0$ and antagonism if FIC $>4.0$. The experiment was done in triplicate.

\section{In vivo assessment}

\section{Mice and environmental conditions}

In this study, 4-week old male, pathogen free ICR (CD-1) mice were purchased from InVivos (Singapore) and used to assess the in vivo toxicity and antibacterial efficacy of the novel peptides, as these animals are by far the most commonly used model for the study of pneumococcal disease (Chiavolini, Pozzi \& Ricci, 2008). The mice were kept in ventilated polycarbonate cages (12 h light/dark cycle, $20 \pm 2{ }^{\circ} \mathrm{C}$ and $55 \%$ relative humidity). All mice were familiarized for 7 days

before any experimental procedure and were given unlimited pellets and water ad libitum. All animal experimentations were conducted according to the guidelines approved by Faculty of Medicine Institutional Animal Care and Use Committee (FOM IACUC), University of Malaya (ethics Reference no. : 2013-07-15/MMBTR/SDS).

\section{In vivo toxicity}

In order to evaluate the possible toxic effects correlated to peptides administered in mice, four hybrid peptides RN7-IN10, RN7-IN9, RN7-IN8 and RN7-IN6 were chosen for in vivo toxicity assessment, due to their promising in vitro antibacterial activity (Jindal et al., 2015). Mice were separated into 4 groups (each with 4 mice) and were injected with respective peptides at $1 \mathrm{~h}, 12 \mathrm{~h}$, 
217 and $24 \mathrm{~h}$ (three-dose regimen) via IP, SC, and IN administration routes. The hybrid peptides were

218 first administered at high doses $(100 \mathrm{mg} / \mathrm{kg}$ for IP route, $100 \mathrm{mg} / \mathrm{kg}$ for SC routes and $20 \mathrm{mg} / \mathrm{kg}$

219 for IN route). Any abnormal behavior was recorded and survival of mice was noted as well. In

220 case adverse effects such as high physical stress, severe lethargy, physical inactiveness, and/or

221 death were detected, lower graded doses were given. All the administered mice were monitored

222 for 7 days or until death occurred. At day seven post administration, all animals were sacrificed

223 and blood and organs were collected. Untreated mice were used as a control group.

\section{In vivo antipneumococcal activity}

Two pneumococcal infection models developed previously in our lab (Le et al., 2015) were

226

227

228

229

230

231

232

233

234

235

236

237

238

239 used to assess the therapeutic efficacy of peptides in vivo. The systemic infection model was used to mimic pneumococcal bacteremia in humans and the pneumococcal pneumonia model was used to mimic pneumococcal pneumonia in humans. A highly virulent strain was used in both the models. The bacterial isolate was grown overnight on Columbia agar with 5\% sheep blood at 37 ${ }^{\circ} \mathrm{C}$ under $5 \% \mathrm{CO}_{2}$. The bacterial suspension was adjusted to $\mathrm{OD}_{625} 0.08-0.1\left(1 \sim 2 \times 10^{8} \mathrm{CFU} / \mathrm{ml}\right)$. Mice tested for lethal systemic infection were inoculated with $1.5 \times 10^{2} \mathrm{CFU} /$ mouse $(100 \mu \mathrm{l})$ via IP route. Mice used to assess the Pneumococcal pneumonia model were inoculated with pneumococcal cells of $5 \times 10^{3} \mathrm{CFU} /$ mouse $(50 \mu \mathrm{l})$ via the intrathoracic route. Both the infection models caused $100 \%$ death within 2 to 4 days post-infection.

After $1 \mathrm{hr}$ of inoculation, Mice receiving treatment were randomized and divided into six groups. RN7-IN10 and RN7-IN8 were tested at three different doses for each $(5 \mathrm{mg} / \mathrm{kg}, 10 \mathrm{mg} / \mathrm{kg}$ and $20 \mathrm{mg} / \mathrm{kg}$ ) using a group of 10 mice. Graded doses of ceftriaxone $(5 \mathrm{mg} / \mathrm{kg}, 10 \mathrm{mg} / \mathrm{kg}, 20$ $\mathrm{gm} / \mathrm{kg}, 40 \mathrm{mg} / \mathrm{kg}$ and $80 \mathrm{mg} / \mathrm{kg}$ ) were also tested to assess the in vivo antibacterial activity of this antibiotic. Only mice injected with PBS were served as uninfected control. Mice injected with 
240 bacterial inoculum were used as untreated control group and given sterile distilled water only.

241 Survival of mice was documented for seven days or until death. After seven days, the experiment

242 was ended, the blood and homogenates of the five major organs (kidney, brain, spleen, liver and

243 lung) of the surviving mice were plated on Columbia agar with 5\% sheep blood, to detect the 244 presence of pneumococcal cells.

\section{In vivo synergy assessment of peptide/peptide and peptide/ceftriaxone}

After evaluating the in vivo antibacterial activity of the hybrids in the standalone mode, the

in vivo efficiency of the hybrid peptides in combination with each other and with the standard

antibiotic ceftriaxone was carried out. Graded doses of peptide and ceftriaxone were chosen and prepared at $2 \mathrm{X}$ the desired concentration separately in $1 \mathrm{ml}$ tubes, and the volume was $0.1 \mathrm{ml}$. Just before injection, both the drugs were combined, giving the final desired concentration at a volume of $0.2 \mathrm{ml}$. The synergetic effect was then performed in infection models $(n=10)$.

\section{Anesthesia and necropsy}

Mice used to evaluate the in vivo toxicity and antibacterial activity of the hybrid peptides

using the subcutaneous (SC) and intranasal (IN) administration routes, were anesthetized using a combination of a standard dose of xylazine (ilium xylazil-20, $10 \mathrm{mg} / \mathrm{kg}$ ) and ketamine (Narketan ${ }^{\circledR}-10,100 \mathrm{mg} / \mathrm{kg}$ ) through intraperitoneal (IP) injection. After 7 days of treatment, the in vivo toxicity and antibacterial efficacy experiments were ended and the surviving mice were anesthetized. Blood samples for Hematological and biochemical analysis were collected via 
263 cardiac puncture using a 25G syringe (BD bioscience, USA). Whole blood for heamatological

264 analysis was collected in $500 \mu 1$ dipotassium EDTA microtainer tubes (BD Bioscience, USA).

265 About $500 \mu 1$ of blood collected an eppedorff tube and centrifuged at $8000 \mathrm{rpm}$ for $5 \mathrm{~min}$ and then

266 the serum was transferred into a new $1.5 \mathrm{ml}$ tube for biochemistry analysis. The mice were then

267 euthanized by cervical dislocation, dissected and the following organs were collected for

268 histopathology evaluation: lung, kidney, brain, liver and spleen.

269

270

271

272

\section{Hematological and biochemical analysis}

273

For whole blood analysis, the parameters were number of red cells (RBC), number of white

cells (WBC), lymphocytes, monocytes, eosinophil, granulocytes, haemoglobin (Hgb), mean

corpuscular volume (MCV), hematocrit (HCT), platelet Counts (PLT), Mean corpuscular

haemoglobin $(\mathrm{MCH})$ and corpuscular haemoglobin concentration $(\mathrm{MCHC})$. For biochemistry

analysis, the parameters were alanine transaminase (ALT), creatinine, alkaline phosphatase (ALP), aspartate aminotransferase (AST), total bilirubin and urea.

\section{Histopathological examination}

The following organs were collected from all the dissected mice: lung, kidney, brain, spleen, and liver. All tissues were fixed in $10 \%(\mathrm{v} / \mathrm{v})$ buffered formalin and processed for paraffin embedding. Hematoxylin-eosin (HE) was used to stain the histological sections at the 
286

287

288

289

290

291

292

293

294

295

296

297

298

299

300

301

302

303

304

305

306

307

308

\section{Statistical analysis}

GraphPad Prism 5 was used to perform the Statistical analysis. The results were expressed as mean \pm standard deviation. Two-way ANOVA with Bonferroni post-test was used to analyze the significance of the difference between the treated groups and control in ATP assay. One-way ANOVA with post-hoc Dunnett-t test was used to assess the statistical difference between the blood haematogram and blood serum biochemistry parameters of the treated and the untreated control groups in the in vivo toxicity assay. Kaplan-Meier analysis with log-rank test (Mantel-Cox) was used to generate the survival curve for each treated group versus untreated control, for both in vivo antibacterial activity and in vivo synergy assays.

\section{Results}

\section{Effects of hybrid peptides on cell morphology and membrane permeability}

TEM and SEM studies were performed to observe the damaging effect of the hybrid peptides on the pneumococcal cell wall/membrane. The images obtained clearly indicated that all the hybrid peptides were capable of disrupting the integrity of bacterial membranes. As shown in Fig. 1A, the untreated cells appeared with complete cell wall and plasma membrane and therefore preserved the normal integral shape of $S$. pneumoniae. The pneumococcal capsular polysaccharide appeared as a thin layer sheltering the whole cell and the cytoplasm of the cell was compactly packed and occupied the entire space (Fig. 1A, arrow 1). Incubation of pneumococcal cells with hybrid peptides had led to a dramatic effect on the morphology of bacterial surface. After $1 \mathrm{~h}$ of incubation, the hybrid peptides were able to breach the intactness of the cell wall and/or plasma membrane, causing membrane breakage and loss of fragments (Fig. 1B-F, arrow 2). Additionally, our TEM results have revealed that treatment with hybrid peptides has led to the leakage of the 
309 cytoplasmic components to the outer environment through the disruption of the cell wall. As a

310 result, huge halos were detected in the inner space of all these treated cells, leading to cell collapse

311 and death (Fig. 1B-F, arrow 3). Moreover, the TEM results also revealed partial disconnection of

312 the cell wall from the cell membrane in pneumococci treated with hybrid peptides, especially those 313 treated with RN7-IN9, RN7-IN8, RN7-IN7 and RN7-IN6 (Fig. 1C-F, arrow 4).

314 Scanning electron microscopy (SEM) was employed to understand the impact of the hybrid 315 peptides on the morphology of $S$. pneumoniae. As presented in Fig. 2, the hybrid peptides were 316 able to induce significant morphological alterations to pneumococcal cells. The untreated $S$. pneumoniae displayed normal and smooth surface (Fig. 2A, arrow 1), whereas S. pneumoniae treated with hybrid peptides at $8 \times$ MIC appeared with a rough and injured surface (Fig. 2B-F, arrow 2). The numerous fragments observed on the bacterial surface are an indication of cell wall breakage and fragments loss upon treatment with hybrid peptides. This result indicates that hybrid peptides could disrupt and damage the integrity of cell wall/membrane or breach the membrane, which was in agreement with the result of TEM.

In order to evaluate the permeability of the membrane and leakage of intracellular components upon treatment with hybrid peptides, the level of ATP in the supernatant following contact of the pneumococcal cells with hybrid peptides was determined using the ATP release assay. After $1 \mathrm{~h}$ of treatment with hybrid peptide, the levels of ATP released after $1 \mathrm{~h}$ of treatment with RN7-IN10 and RN7-IN9 were the highest among the five hybrid peptides tested (54.5 \pm 4.7 and 42.27 \pm 92 pM respectively) (Fig. 3). The ATP efflux steadily decreased, and the ATP release reached $25.42 \pm 3.51 \mathrm{pM}$ and $22.9 \pm 3.22 \mathrm{pM}$ after $3 \mathrm{~h}$ of treatment with RN7-IN10 and RN7-IN9

(Fig. 3). On the other hand, the quantities of ATP released from pneumococcal cells upon 331 incubation with RN7-IN8, RN7-IN7 and RN7-IN6 after 1 h were 39.03 $\pm 0.2 \mathrm{pM}, 22.35 \pm 0.9 \mathrm{pM}$ 
332 and $14.8 \pm 0.35 \mathrm{pM}$. The levels of ATP release from pneumococcal cells treated with RN7-IN8, 333 RN7-IN7 and RN7-IN6 were $20.54 \pm 1.03 \mathrm{pM}, 13.02 \pm 2.26 \mathrm{pM}$ and $11.47 \pm 0.32 \mathrm{pM}$ respectively 334 after $3 \mathrm{~h}$ of treatment (Fig. 3). However, all the hybrid peptides showed better capacity in efflux

335 ATP from pneumococcal cells, in comparison with standard antibacterial drugs ceftriaxone and 336 erythromycin. The efflux levels of ATP by ceftriaxone and erythromycin treated cells after $1 \mathrm{~h}$ of 337 incubation were $5.24 \pm 1.43 \mathrm{pM}$ and $0.49 \pm 0.004 \mathrm{pM}$, respectively (Fig. 3).

338

\section{DNA retardation activity}

To clarify the influence of the hybrid peptides on pneumococcal genomic DNA, the retardation of DNA by the hybrid peptides at various concentrations was assessed by analyzing electrophoretic movement of pneumococci DNA bands through the agarose gel $(1 \%$, w/v). Our results clearly indicated that like their parent peptide indolicidin, all the five hybrid peptides were capable of inhibiting DNA migration through the gel at a concentration of $62.5 \mu \mathrm{g} / \mathrm{ml}$ (Fig. 4A-F).

On the other hand, the standard drugs ceftriaxone and erythromycin could not prevent the migration of DNA band through the agarose gel up to a concentration of $500 \mu \mathrm{g} / \mathrm{ml}$ (Fig. 4G \& $4 \mathrm{H})$.

In vitro synergistic effects of peptide/peptide and peptide/antibiotic combinations

The in vitro antibacterial activity of peptide/peptide and peptide/antibiotic combinations was evaluated using the chequerboard dilution assay. Our results reveal that combinations of hybrid peptides (RN7-IN10, RN7-IN9, RN7-IN8, RN7-IN7, and RN7-IN6) with each other pneumococcal isolates towards standard drugs. Likewise, combinations of standard drugs 
355 ceftriaxone and erythromycin with all five hybrid peptides presented synergistic effects with

356 fractional inhibitory concentration (FIC) index of $\leq 0.5$ against both isolates of $S$. pneumoniae,

357 regardless of their susceptibility to antibiotics (Table 2). These results indicate that all the hybrid

358 peptides were able to enhance the antibacterial activity of both the standard drugs ceftriaxone and 359 erythromycin.

\section{In vivo toxicity of hybrid peptides}

The in vivo toxicity of four hybrid peptides namely RN7-IN10, RN7-IN9, RN7-IN8 and

RN7-IN6 was evaluated following a three dose regimen with the mice at $1 \mathrm{~h}, 12 \mathrm{~h}$ and $24 \mathrm{~h}$ using

three different administration routes. The results revealed that in the case of mice treated with all hybrid peptides via subcutaneous (SC) injection at the maximum dose $(100 \mathrm{mg} / \mathrm{kg})$, no animal differences were noted for mice given RN7-IN10 via SC, which displayed significantly lower granulocytes $(\mathrm{p}=0.0172)$ and ALP $(\mathrm{p}=0.0037)($ Table $\mathrm{S} 1$, highlighted in yellow), while Mice treated with RN7-IN6 displayed significantly higher platelet counts $(p=0.0487)$ in comparison with the control group (Table S1, highlighted in blue). Histopathological studies were performed with the lung, brain, liver, spleen and kidney of control and treated animals. No histological abnormalities were detected in the organs of any group, as all the tissue sections were normal and 373 did not display differences with the control group (Fig. S1). Similarly, no abnormal physical

374 behavior was noted upon giving the mice hybrid peptides via the intranasal (IN) route. However, treatment with RN7-IN9 displayed significantly lower MCV ( $\mathrm{p}=0.001)$ (Table S2, highlighted in yellow) than the control group. Mice treated with RN7-IN6 displayed significantly lower

377 percentage of granulocytes $(\mathrm{p}=0.0482)($ Table $\mathrm{S} 2$, highlighted in blue), as compared to the control 
378

379

380

381

382

383

384

385

386

387

388

389

390

391

392

393

394

395

396

397

398

399

400

group. Histological examination of the organs collected from all the treated and control groups did not expose any histopathological changes (Fig. S2).

In terms of the intraperitoneal (IP) administration route, all four hybrid peptides caused death and/or high physical stress when injected at a concentration of $100 \mathrm{mg} / \mathrm{kg}$. Therefore, low graded doses were attempted until we reached the maximum dose at which no signs of stress or abnormal behavior were evident. Hybrid peptides RN7-IN10 and RN7-IN8 did not display any sign of toxicity when injected at $20 \mathrm{mg} / \mathrm{kg}$; no death occurred in any of the treated mice up to 7 days post-treatment. RN7-IN9 and RN7-IN6 were non-toxic when injected at $10 \mathrm{mg} / \mathrm{kg}$. None of the five major organs of the treated mice revealed any significant histological abnormality, as compared to the untreated control group (Fig. S3). However, mice treated with RN7-IN9 (10 $\mathrm{mg} / \mathrm{kg})$ via IP route showed significantly lower lymphocytes $(\mathrm{p}=0.0445)$ and lower ALP $(\mathrm{p}=$ 0.0187) (Table S3, highlighted in yellow), while RN7-IN6 treated mice had lower ALT ( $\mathrm{p}=$ 0.0425) when compared to the control group (Table S3, highlighted in blue).

\section{In vivo antibacterial efficacy of hybrid peptides}

Two peptides, RN7-IN10 and RN7-IN8, which showed the fastest killing kinetics (Jindal et al., 2015) and exhibited less toxic effects in vivo were selected to evaluate their in vivo antibacterial efficacy via IP route. Both hybrid peptides were tested at three different doses (5 $\mathrm{mg} / \mathrm{kg}, 10 \mathrm{mg} / \mathrm{kg}$ and $20 \mathrm{mg} / \mathrm{kg}$ ) in three treatment regimens (1 h, $12 \mathrm{~h}$ and $24 \mathrm{~h}$ post-infection). In the pneumococcal bacteremia model, both RN7-IN10 and RN7-IN8 failed to treat any of the infected mice at $5 \mathrm{mg} / \mathrm{kg}$. At a dose of $10 \mathrm{mg} / \mathrm{kg}, 10 \%$ of the infected mice survived after treatment with RN7-IN10 ( $\mathrm{p}=0.0018)$, whereas $30 \%$ of the mice was able to survive after treatment with RN7-IN8 ( $\mathrm{p}=0.0002)$. However, at a dose of $20 \mathrm{mg} / \mathrm{kg}, 30 \%$ of the mice treated with RN7-IN10 
401 survived $(\mathrm{p}<0.0001)$, while $50 \%$ of the mice survived when treated with hybrid peptide RN7-IN8

$402(p=0.0002)$ (Fig. 5). No pneumococci were detected from the blood of the mice that survived and

403 none of the mice showed presentation of illness, as compared to the untreated group which was

404 severely ill and inactive. Treatment via SC and IN routes had no impact on infected mice up to 405 seven days post-infection and none of the mice survived.

406 In addition to our designed peptides, ceftriaxone, as a standard drug, was used to treat 407 infected mice via IP route at $5 \mathrm{mg} / \mathrm{kg}, 10 \mathrm{mg} / \mathrm{kg}, 20 \mathrm{mg} / \mathrm{kg}, 40 \mathrm{mg} / \mathrm{kg}$, and $80 \mathrm{mg} / \mathrm{kg}$ and the 408 survival was $10 \%, 30 \%, 40 \%, 70 \%$ and $90 \%$ up to seven days post-infection $(\mathrm{p}<0.0001)$ (Fig. 6).

409 In the pneumococcal pneumonia model, none of the mice treated with both peptides via IP, SC 410 and IN routes survived up to seven days post-infection and therefore, this model was excluded 411 from further studies.

412 Combinations of peptide-peptide were also assessed for their ability to treat infected mice 413 with pneumococcal bacteremia. Two combinations were used, $5 \mathrm{mg} / \mathrm{kg}+5 \mathrm{mg} / \mathrm{kg}$ and $10 \mathrm{mg} / \mathrm{kg}$ $414+10 \mathrm{mg} / \mathrm{kg}$ to treat mice via IP route at three regimens $1 \mathrm{~h}, 12 \mathrm{~h}$ and $24 \mathrm{~h}$. The results indicate that 415 the combination of $5 \mathrm{mg} / \mathrm{kg}+5 \mathrm{mg} / \mathrm{kg}$ was able to treat $40 \%$ of the mice and protected them from 416 death up to 7 day post-infection $(\mathrm{p}=0.0003)$, while increasing the dose to $10 \mathrm{mg} / \mathrm{kg}$ of each peptide 417 resulted in $60 \%$ of the infected mice surviving the pneumococcal infection $(\mathrm{p}<0.001)$ (Fig. 7). 418 These findings are in agreement with our in vitro synergism results which showed that hybrid 419 peptides are able to enhance the biological activity of each other.

In vivo synergy assessment of hybrid peptide RN7-IN8 in combination with ceftriaxone Among the hybrid peptides RN7-IN10 and RN7-IN8, standalone treatment with RN7-IN8

423 at $20 \mathrm{mg} / \mathrm{kg}$ was found to confer significant survivability on mice infected by a highly virulent 
424 pneumococcal clinical isolate via IP route. To assess the synergistic effect of RN7-IN8 in 425 combination with the standard drug ceftriaxone (CTX), three different doses of RN7-IN8 (5 mg/kg, $42610 \mathrm{mg} / \mathrm{kg}$ and $20 \mathrm{mg} / \mathrm{kg})$ and ceftriaxone $(5 \mathrm{mg} / \mathrm{kg}, 10 \mathrm{mg} / \mathrm{kg}$ and $20 \mathrm{mg} / \mathrm{kg})$ were tested, using

427 the same bacteremia infection model in three treatment formulations: $\mathrm{RN} 7-\mathrm{IN}_{5}-\mathrm{CTX}_{5}(5 \mathrm{mg} / \mathrm{kg}$ 428 of RN7-IN8 and $5 \mathrm{mg} / \mathrm{kg}$ of CTX), RN7-IN8 ${ }_{10}-\mathrm{CTX}_{10}(10 \mathrm{mg} / \mathrm{kg}$ of RN7-IN8 and $10 \mathrm{mg} / \mathrm{kg}$ of $429 \mathrm{CTX})$ and RN7-IN8 $20-\mathrm{CTX}_{20}(20 \mathrm{mg} / \mathrm{kg}$ of RN7-IN8 and $20 \mathrm{mg} / \mathrm{kg}$ of CTX). Using groups of 10 430 mice, the combinations of RN7-IN8 and ceftriaxone RN7-IN8 ${ }_{5}-\mathrm{CTX}_{5}(5 \mathrm{mg} / \mathrm{kg}$ of RN7-IN8 and $4315 \mathrm{mg} / \mathrm{kg}$ of CTX), RN7-IN8 $10^{-} \mathrm{CTX}_{10}(10 \mathrm{mg} / \mathrm{kg}$ of RN7-IN8 and $10 \mathrm{mg} / \mathrm{kg}$ of CTX $)$ and RN7$432 \mathrm{IN}_{20}-\mathrm{CTX}_{20}(20 \mathrm{mg} / \mathrm{kg}$ of RN7-IN8 and $20 \mathrm{mg} / \mathrm{kg}$ of CTX) led to survival rates of $60 \%, 80 \%$ 433 and $100 \%$ in mice infected with highly virulent pneumococcal strain up to seven days post434 infection $(\mathrm{p}<0.0001)$ (Fig. 8). Our results displayed that treatment using combinations of peptide435 antibiotics conferred higher survival rate than peptide and antibiotic in their stand-alone form. In 436 addition, all treated mice which survived from the infection appeared physically active and none 437 of them showed signs of abnormal behavior.

\section{Histopathological evaluation}

All the histopathological examinations of the mice infected with bacteremia model with and without treatment are presented in Fig. 9 and Fig. 10. Out of the five major organs examined, the lung and spleen of the infected animals were the most severely affected. A number of histopathological changes were observed in the lung of the infected mice. As compared to the uninfected control group, the lung of the infected and untreated group exhibited extensive vascular

446 congestion with foci consolidation. Heavy permeation of the red blood cells into the alveolar 
447 spaces strongly denoted pulmonary hemorrhage (Fig. 9A, arrow a). The greatly congested lung

448 appeared with little alveolar spaces (Fig. 9A, arrow b). This is in contrast to the uninfected group,

449 where the normal lung displayed greatly aerated alveolar spaces with a thin layer of the alveolar

450 wall (Fig. 9B). Severe tissue injuries was also noticed in the spleen of the infected group (Fig.

451 10A). Unlike the normal spleen which showed normal red and white pulps (Fig. 10B, arrow b),

452 the infected spleen demonstrated depleted splenocytes with no white matter/germinal center (Fig.

$45310 \mathrm{~A}$, arrow a). No significant histopathological lesions were observed in other organs, such as the

454 brain, liver, kidney and heart.

455 For the respective treatments of infected mice including hybrid peptide RN7-IN8 at 20

$456 \mathrm{mg} / \mathrm{kg}$, combination of hybrid peptides RN7-IN10 and RN7-IN8 (10 mg/kg $+10 \mathrm{mg} / \mathrm{kg})$ and

457 combination of RN7-IN8 and ceftriaxone $(5 \mathrm{mg} / \mathrm{kg}+5 \mathrm{mg} / \mathrm{kg}, 10 \mathrm{mg} / \mathrm{kg}+10 \mathrm{mg} / \mathrm{kg}$ and $20 \mathrm{mg} / \mathrm{kg}$

$458+20 \mathrm{mg} / \mathrm{kg}$ ), it was noticed that although lesions, inflammatory events and the degree of tissues

459 damage were found in the organs, the degree and severity of the damage were significantly less

460 than the infected control group. Unlike the lung of the untreated mice which exhibited severe

461 inflammation and the alveolar spaces were about 90\% congested (Fig. 9A), all the lungs harvested

462 from the treated mice revealed only low level of congestion and minor thickening of the alveolar

463 wall, even though these histological changes were still noticeable in the mice (Fig. 9C-G).

464 Treatment of infected mice with a combination of hybrid peptide RN7-IN8 and ceftriaxone at three

465 different dosages $(5 \mathrm{mg} / \mathrm{kg}-5 \mathrm{mg} / \mathrm{kg}, 10 \mathrm{mg} / \mathrm{kg}-10 \mathrm{mg} / \mathrm{kg}$ and $20 \mathrm{mg} / \mathrm{kg}-20 \mathrm{mg} / \mathrm{kg}) \mathrm{showed}$

466 gradual decrease in the degree of congestion and damage (Fig. 9E-G). Lungs harvested from mice

467 treated with a combination of RN7-IN8 and ceftriaxone at $20 \mathrm{mg} / \mathrm{kg}+20 \mathrm{mg} / \mathrm{kg}$ (Fig. 9G) which

468 presented $100 \%$ mice survival, were similar to those harvested from the uninfected control mice

469 (Fig. 9B) in degree of normality. Likewise, all the spleens of treated mice displayed no or minimum 
470 damage, with the white and red pulps being clearly observed (Fig. 10C-G), as compared to the

471 infected one (Fig. 10A). No significant tissue damage was observed in the brain, kidney and liver

472 in both treated and untreated mice.

473

474

\section{Discussion}

475

We report here the mechanisms of actions, in vivo toxicity and antibacterial efficiency of

476 five hybrid peptides designed earlier in our lab, based on two templates, indolicidin and ranalexin.

477 TEM and SEM were used to evaluate the morphological alterations caused by hybrid peptides.

478 Results obtained from TEM displayed strong evidence that targeting the bacterial cell wall/plasma

479 membrane is the main antibacterial mechanism used by hybrid peptides. Unlike the untreated cells,

480 pneumococcal cells treated with hybrid peptides faced dramatic morphological changes. The

481 breakage and fragments loss of the bacterial cell wall/membrane is probably a result of the strong

482 interaction between the negatively charged membrane and the hybrid peptides due to their positive

483 charge and high hydrophobic content (Jindal et al., 2015). Unlike the normal mammalian cell

484 membranes, bacterial membranes are richer in highly electronegative lipids such as

485 phosphatidylserine (PS), cardiolipin (CL) or phosphatidylglycerol (PG). These acidic

486 phospholipids tend to make the bacterial membrane highly negative in charge and thus attract the

487 positively charged antimicrobial peptides to attach to the bacterial membranes and make them

488 preferred by AMPs over mammalian membranes (Ghavami et al., 2008). To the contrary, the

489 membrane of mammalian cells is enriched with zwitterionic phospholipids such as sphingomyelin

490 (SM), phosphatidylethanolamine (PE) or phosphatidylcholine (PC), which are neutral in net

491 charge. These substances prevent the amalgamation of peptide molecules into cell membranes and

492 thus prevent pores formation (Yeaman \& Yount, 2003). In addition to their positive charge, these 
493 five hybrid peptides have a high content of hydrophobic residues. Peptide hydrophobicity is 494 another critical property that governs the attraction of AMPs toward bacterial membrane, as it 495 directs the level to which an AMP can penetrate into the lipid bilayer (Yeaman \& Yount, 2003). 496 The high content of tryptophan (Trp) is another advantage of these hybrids. It is well known that 497 Trp has a significant role in the interaction of antimicrobial peptides with the bacterial membrane, 498 as this amino acid strongly prefer the interfacial regions of lipid bilayers. In certain cases, Trp is 499 considered hydrophobic due to its uncharged sidechain. However, it is observed that Trp residues 500 do not reside in the hydrocarbon region of lipid bilayers and accordingly it is placed towards the 501 more hydrophilic side of the scale (Chan, Prenner \& Vogel, 2006). Another key factor of this 502 amino acid is its ability to form an extensive $\pi$-electron system. Cation $-\pi$ interaction occurs 503 between the cationic sidechains of the basic amino acids arginine (Arg) or lysine (Lys) and the 504 aromatic sidechains of the aromatic amino acids tryptophan (Trp), tyrosine (Tyr) or phenylalanine 505 (Phe) (Gallivan \& Dougherty, 1999). Cation- $\pi$ interactions are significant for peptide self506 association inside membranes and enable deeper insert into membranes by sheltering the cationic 507 side chains (Torcato et al., 2013). The detachment of the cytoplasmic membrane from cell wall 508 observed in pneumococcal cells upon treatment with hybrid peptides, is a possible indication of 509 the capability of hybrid peptides to interpolate themselves between pyrophosphate-linked cell-wall 510 anchors and the cell membrane. Subsequently, this act would pullout the isoprenyl anchor chains 511 away from the cell membrane and weaken cell-wall adhesion. The results obtained by TEM were 512 similar to those reported on the mechanism of nisin against B. subtilis (Hyde et al., 2006) and E. 513 faecalis (Tong et al., 2014). Another possible explanation is that the breakage of the cell wall 514 allows the insertion of water from the medium into the space between the two membranes and 515 detach them (López-Expósito, Amigo \& Recio, 2008). Likewise, SEM studies showed the 
516 damaging effects of hybrid peptides on the bacterial surface. Unlike the untreated cells which

517 appeared with normal and smooth cell surface, pneumococcal cells incubated with hybrid peptides

518 were appeared with swelling and aggregation. Besides, the numerous fragments observed in $S$.

519 pneumoniae cultures treated with hybrid peptides point to a cell wall breakage and cell lysis.

520 Membrane disruption could be associated with leakage of ions and metabolites, depolarization and

521 eventually cell death. Adenosine triphosphate (ATP) is one of most significant molecules for all

522 living cells, as it used as an intracellular source of energy for many biological processes (Mempin

523 et al., 2013). In normal conditions, bacterial membranes are impervious to the efflux of ATP and

524 other intracellular constituents, as membrane destabilization might lead to the release of normally

525 impervious substances. Our results revealed that the ATP efflux was not increased by the

526 incubation of pneumococcal cells with standard drugs ceftriaxone and erythromycin, but was

527 increased by incubation with hybrid peptides. Although ceftriaxone is a member of the $\beta$-lactam

528 family of antibiotics, its ability of releasing intracellular ATP was less than that of the hybrid

529 peptides. This is probably due to the fact that AMPs exert their antimicrobial activity faster than

530 standard drugs. As we have shown in our previous paper, the hybrid peptides were able to exert

531 their bactericidal activity within one hour of incubation with resistant S. pneumoniae, whereas

532 ceftriaxone could not eliminate $S$. pneumoniae up to $240 \mathrm{~min}$ of incubation (Jindal et al., 2015).

533 The ATP efflux results suggest that our positively charged hybrid peptides have strong affinity to

534 bind to the negatively charged bacterial membrane, disrupting its integrity and allowing a

535 significant amount of ATP to be released to the surrounding environment. However, a reduction

536 in the amount of ATP released to the medium was noticed after $1 \mathrm{hr}$ of incubation; this might be

537 due to the rapid degradation of ATP by enzymes released to the medium as a result of membrane

538 damage, which subsequently leads to rapid cell death. Such results were also observed when 
539 Candida albicans was treated with CATH-2 peptide; the levels of ATP released after 5 min of

540 incubation were higher than the levels of ATP after $1 \mathrm{hr}$ of incubation (Ordonez et al., 2014).

541 Altogether, results from the TEM, SEM and ATP release assay indicate that the hybrid peptides

542 destabilize the cell envelope of the pneumococcal cells. Hence, it can be hypothesized that the

543 disturbance of the bacterial surface must activate an autolytic and/or cell death mechanism.

544 It is well known that the cell membrane is not the only target for antimicrobial peptides.

545 AMPs may also attack other cell components such as DNA, RNA or proteins (Li et al., 2013). For

546 instance, the antimicrobial peptide buforin II has the ability to translocate itself to the inner leaflet

547 of the plasma membrane and target the DNA after breaching the membranes, resulting in rapid

548 cell death (Park, Kim \& Kim, 1998). Like their parent peptide indolicidin which has been shown

549 to target and inhibit DNA synthesis as one of its mechanisms of action (Subbalakshmi \& Sitaran,

550 1998; Marchand et al., 2006), all the hybrid peptides were capable of binding to DNA efficiently

551 and preventing it from moving down through the agarose gel. These results suggest that hybrid

552 peptides could possess another mechanism of bacterial killing, by inhibiting intracellular functions

553 via interference with DNA function. Hsu and co-workers have revealed through their work that

554 the ability of the parent peptide indolicidin to permeabilize bacterial membranes is not the only

555 mechanism of antimicrobial action. Indolicidin is also capable of binding efficiently to DNA and

556 form a complex. The ability of indolicidin to penetrate the cell membrane allows the peptide to

557 translocate itself to the cytoplasm and bind to the negatively charged DNA via its positive charge

558 (Hsu et al., 2005). Moreover, Ghosh and co-workers have identified the central motif (PWWP) of

559 Indolicidin responsible of stabilizing the DNA duplex and thus inhibiting DNA replication and

560 transcription. The two tryptophan residues of the central motif play a significant role in

561 stabilization of the duplex by desolvating the core of the DNA (Ghosh et al., 2014). This motif is 
562 conserved in our hybrid peptides and therefore, we hypothesize that the hybrid peptides like their 563 parent indolicidin are most probably able to bind to bacterial DNA and preventing its intracellular

564 function. The interaction of peptides with bacterial DNA can prevent or hinder gene expression,

565 which is an efficient way to suppress and inhibit normal enzyme and receptor synthesis, damaging

566 the intracellular components required for the life cycle of the bacterial cell and thus leads to cell

567 death.

568 Combinations of antimicrobial agents are often used to combat multi-drug resistant isolates

569 (Novy et al., 2011). Several studies have reported synergistic effects of combinations of AMPs 570 with standard antibiotics. The hybrid peptide LHP7 revealed a synergistic effect against a clinical

571 isolate of methicilin-resistant $S$. aureus MRSA, when combined with ampicillin (Xi et al., 2013).

572 In the present study, we utilized the chequerboard MIC technique to assess peptide-drug 573 interaction. Our results revealed that all the five hybrid peptides exhibited synergistic effects 574 against pneumococcal clinical isolate, when combined with each other and with conventional 575 drugs erythromycin and ceftriaxone. One possible explanation of the synergistic effects of 576 peptides-drug combinations is that the hybrid peptides may increase permeability by interacting 577 with the bacterial cell wall/membrane, making it easier for conventional drugs to act on their 578 targets. Previous reports have shown that $\beta$-lactam antibiotics like ceftriaxone exert higher 579 antimicrobial activity, when combined with membranolytic peptides such as nisin, as these AMPs 580 cause changes in cell morphology by forming pores, allowing antibiotics to enhance their action 581 and produce a greater damage within the cell wall (Singh, Prabha \& Rishi, 2013; Tong et al., 2014). 582 Another possible mechanism of synergistic combinations is that the antimicrobial peptides alter 583 the efflux pump systems, allowing intracellular antibiotics such as macrolides to act more 584 efficiently on their intracellular targets (Ruhr \& Sahl, 1985; Soren et al., 2015). 

therapy with both $\beta$-lactam and macrolide had a significantly lower case - mortally rate, in comparison with a single antibiotic therapy (Mufson \& Stanek, 2006). Broad-spectrum cephalosporins such as ceftriaxone are important antibiotics in the management of invasive diseases induced by penicillin-resistant pneumococci. However, the rate of pneumococcal strains resistant to ceftriaxone has increased significantly (Chiu et al., 2007). Hence, RN7-IN8, which showed significant therapeutic efficacy in the infected mice in its standalone form, was further assessed for in vivo therapeutic synergism in combination with ceftriaxone. Combination of RN7-

IN8 and ceftriaxone resulted in a synergistic effect, when tested in vivo using mice infected with pneumococcal bacteremia model. The survival rates in mice treated with this combination at varying dosages increased dramatically as compared to the sum of the survival rates of standalone treatment. These findings are in agreement with our in vitro synergism results which demonstrated that hybrid peptides and ceftriaxone can act synergistically and kill pneumococci rapidly. Unlike untreated mice that died within four days after infection, $100 \%$ of mice treated with combination of RN7-IN8 and ceftriaxone (20 mg/kg - $20 \mathrm{mg} / \mathrm{kg})$ survived at day seven post-infection. Using a combination of these two drugs at a low dose $(20 \mathrm{mg} / \mathrm{kg})$ showed better survival rate than the use

606 behavior.

\section{5. Conclusion}


against $S$. pneumoniae. The results of the in vitro and in vivo synergism tests clearly presented that

610

611

612

613

614

615

616

617

618

619

620

621

622

623

624

625

626

627

628

629

630

631

632

633

634

635

636

the hybrids are not only potent antimicrobials in their standalone form, but also when combined

with standard antibiotics, suggesting that these peptides can be used as supporting compounds to reduce the therapeutic dose of antibiotics, thus reducing potential resistance. Although RN7-IN8 showed promising therapeutic outcome, there are some limitations in its efficacy. Primarily, the peptide had no effect on the pneumonia model, where the bacterial inoculum was administered directly into the thoracic cavity to infect the lungs, while the peptide was given at distant sites, indicating that the peptide could not diffuse effectively to the site of infection. This could possibly

be due to the degradation by blood or cellular components. On the other hand, the effectiveness of the peptide in the bacteremia model is probably due to both infection and treatment being carried out at the same site. Hence, AMPs have a huge potential to play a crucial role in combating resistant bacteria, either as standalone therapeutics or in combination with other drugs.

\section{References}

Bajaksouzian S., Visalli MA., Jacobs MR., Appelbaum PC. 1996. Antipneumococcal activities of cefpirome and cefotaxime, alone and in combination with vancomycin and teicoplanin, determined by checkerboard and time-kill methods. Antimicrobial Agents and Chemotherapy 40:1973-1976.

Bravo LC. 2009. Overview of the disease burden of invasive pneumococcal disease in Asia. Vaccine 27:7282-91. DOI: 10.1016/j.vaccine.2009.04.046.

Caballero J., Rello J. 2011. Combination antibiotic therapy for community-acquired pneumonia. Annals of Intensive Care 1:48. DOI: 10.1186/2110-5820-1-48.

Cao J., Chen D., Xu W., Chen T., Xu S., Luo J., Zhao Q., Liu B., Wang D., Zhang X., Shan Y., Yin Y. 2007. Enhanced protection against pneumococcal infection elicited by immunization with the combination of PspA, PspC, and ClpP. Vaccine 25:4996-5005. DOI: 10.1016/j.vaccine.2007.04.069.

Chan DI., Prenner EJ., Vogel HJ. 2006. Tryptophan- and arginine-rich antimicrobial peptides: structures and mechanisms of action. Biochimica et Biophysica Acta 1758:1184-202. DOI: 
637

638

639

640

641

642

643

644

645

646

647

648

649

650

651

652

653

654

655

656

657

658

659

660

661

662

663

664

665

666

667

668

669

670

671

672

673

674

675

676

677

678

\subsection{6/j.bbamem.2006.04.006.}

Chiavolini D., Pozzi G., Ricci S. 2008. Animal models of Streptococcus pneumoniae disease. Clinical Microbiology Reviews 21:666-685. DOI: 10.1128/CMR.00012-08.

Chiu C-H., Su L-H., Huang Y-C., Lai J-C., Chen H-L., Wu T-L., Lin T-Y. 2007. Increasing ceftriaxone resistance and multiple alterations of penicillin-binding proteins among penicillin-resistant Streptococcus pneumoniae isolates in Taiwan. Antimicrobial Agents and Chemotherapy 51:3404-6. DOI: 10.1128/AAC.01563-06.

Clinical and Laboratory Standards Institute. 2012. Methods for Dilution Antimicrobial Susceptibility Tests for Bacteria That Grow Aerobically; Approved Standard - Ninth Edition. Wayne, Pennsylvania: Clinical and Laboratory Standards Institute.

Cornick JE., Bentley SD. 2012. Streptococcus pneumoniae: the evolution of antimicrobial resistance to beta-lactams, fluoroquinolones and macrolides. Microbes and Infection / Institut Pasteur 14:573-83. DOI: 10.1016/j.micinf.2012.01.012.

Deslouches B., Steckbeck JD., Craigo JK., Doi Y., Mietzner T a., Montelaro RC. 2013. Rational design of engineered cationic antimicrobial peptides consisting exclusively of arginine and tryptophan, and their activity against multidrug-resistant pathogens. Antimicrobial Agents and Chemotherapy 57:2511-2521. DOI: 10.1128/AAC.02218-12.

Gallivan JP., Dougherty DA. 1999. Cation-pi interactions in structural biology. Proceedings of the National Academy of Sciences of the United States of America 96:9459-64.

Ghavami S., Asoodeh A., Klonisch T., Halayko AJ., Kadkhoda K., Kroczak TJ., Gibson SB., Booy EP., Naderi-manesh H., Los M. 2008. Brevinin-2R 1 semi-selectively kills cancer cells by a distinct mechanism, which involves the lysosomal-mitochondrial death pathway. 12:1005-1022. DOI: 10.1111/j.1582-4934.2007.00129.x.

Ghosh A., Kar RK., Jana J., Saha A., Jana B., Krishnamoorthy J., Kumar D., Ghosh S., Chatterjee S., Bhunia A. 2014. Indolicidin targets duplex DNA: Structural and mechanistic insight through a combination of spectroscopy and microscopy. ChemMedChem 9:20522058. DOI: $10.1002 / \mathrm{cmdc} .201402215$.

Hsu C-H., Chen C., Jou M-L., Lee AY-L., Lin Y-C., Yu Y-P., Huang W-T., Wu S-H. 2005. Structural and DNA-binding studies on the bovine antimicrobial peptide, indolicidin: evidence for multiple conformations involved in binding to membranes and DNA. Nucleic Acids Research 33:4053-64. DOI: 10.1093/nar/gki725.

Hyde AJ., Parisot J., McNichol A., Bonev BB. 2006. Nisin-induced changes in Bacillus morphology suggest a paradigm of antibiotic action. Proceedings of the National Academy of Sciences of the United States of America 103:19896-901. DOI: 10.1073/pnas.0608373104.

Jacobs MR. 2004. Streptococcus pneumoniae: Epidemiology and patterns of resistance. The American Journal of Medicine Supplements 117:3-15. DOI: 10.1016/j.amjmed.2004.07.003.

Jindal HM., Le CF., Mohd Yusof MY., Velayuthan RD., Lee VS., Zain SM., Isa DM., Sekaran SD. 2015. Antimicrobial Activity of Novel Synthetic Peptides Derived from Indolicidin and Ranalexin against Streptococcus pneumoniae. PloS One 10:e0128532. DOI: 10.1371/journal.pone.0128532. 
679

680

681

682

683

684

685

686

687

688

689

690

691

692

693

694

695

696

697

698

699

700

701

702

703

704

705

706

707

708

709

710

711

712

713

714

715

716

717

718

719

720

Le C-F., Yusof MYM., Hassan MAA., Lee VS., Isa DM., Sekaran SD. 2015. In vivo efficacy and molecular docking of designed peptide that exhibits potent antipneumococcal activity and synergises in combination with penicillin. Scientific Reports 5:11886. DOI: $10.1038 /$ srep 11886.

Li L., Shi Y., Cheserek MJ., Su G., Le G. 2013. Antibacterial activity and dual mechanisms of peptide analog derived from cell-penetrating peptide against Salmonella typhimurium and Streptococcus pyogenes. Applied Microbiology and Biotechnology 97:1711-23. DOI: 10.1007/s00253-012-4352-1.

López-Expósito I., Amigo L., Recio I. 2008. Identification of the initial binding sites of alphas2casein $\mathrm{f}(183-207)$ and effect on bacterial membranes and cell morphology. Biochimica et Biophysica Acta 1778:2444-9. DOI: 10.1016/j.bbamem.2008.06.018.

Marchand C., Krajewski K., Lee HF., Antony S., Johnson AA., Amin R., Roller P., Kvaratskhelia M., Pommier Y. 2006. Covalent binding of the natural antimicrobial peptide indolicidin to DNA abasic sites. Nucleic Acids Research 34:5157-5165. DOI: 10.1093/nar/gk1667.

Mempin R., Tran H., Chen C., Gong H., Kim Ho K., Lu S. 2013. Release of extracellular ATP by bacteria during growth. BMC Microbiology 13:301. DOI: 10.1186/1471-2180-13-301.

Moschioni M., De Angelis G., Harfouche C., Bizzarri E., Filippini S., Mori E., Mancuso G., Doro F., Barocchi M a., Ruggiero P., Masignani V. 2012. Immunization with the RrgB321 fusion protein protects mice against both high and low pilus-expressing Streptococcus pneumoniae populations. Vaccine 30:1349-56. DOI: 10.1016/j.vaccine.2011.12.080.

Mufson MA., Stanek RJ. 2006. Revisiting Combination Antibiotic Therapy for CommunityAcquired Invasive Streptococcus pneumoniae Pneumonia. Clinical Infectious Diseases 42:304-306. DOI: 10.1086/499110.

Novy P., Urban J., Leuner O., Vadlejch J., Kokoska L. 2011. In vitro synergistic effects of baicalin with oxytetracycline and tetracycline against Staphylococcus aureus. Journal of Antimicrobial Chemotherapy 66:1298-1300. DOI: 10.1093/jac/dkr108.

O’Brien KL., Wolfson LJ., Watt JP., Henkle E., Deloria-Knoll M., McCall N., Lee E., Mulholland K., Levine OS., Cherian T. 2009. Burden of disease caused by Streptococcus pneumoniae in children younger than 5 years: global estimates. Lancet 374:893-902. DOI: 10.1016/S0140-6736(09)61204-6.

Ordonez SR., Amarullah IH., Wubbolts RW., Veldhuizen EJ a., Haagsman HP. 2014. Fungicidal mechanisms of cathelicidins LL-37 and CATH-2 revealed by live-cell imaging. Antimicrobial Agents and Chemotherapy 58:2240-2248. DOI: 10.1128/AAC.01670-13.

Park CB., Kim HS., Kim SC. 1998. Mechanism of action of the antimicrobial peptide buforin II: buforin II kills microorganisms by penetrating the cell membrane and inhibiting cellular functions. Biochemical and Biophysical Research Communications 244:253-7. DOI: 10.1006/bbrc.1998.8159.

Reynolds C a., Finkelstein J a., Ray GT., Moore MR., Huang SS. 2014. Attributable healthcare utilization and cost of pneumonia due to drug-resistant streptococcus pneumonia: a cost analysis. Antimicrobial Resistance and Infection Control 3:16. DOI: 10.1186/2047-2994-316. 
721

722

723

724

725

726

727

728

729

730

731

732

733

734

735

736

737

738

739

740

741

742

743

744

745

746

747

748

749

750

751

752

753

754

755

756

757

758

759

760
Ruhr E., Sahl HG. 1985. Mode of action of the peptide antibiotic nisin and influence on the membrane potential of whole cells and on cytoplasmic and artificial membrane vesicles. Antimicrobial Agents and Chemotherapy 27:841-5. DOI: 10.1128/AAC.27.5.841.

Sánchez-Vásquez L., Silva-Sanchez J., Jiménez-Vargas JM., Rodríguez-Romero A., MuñozGaray C., Rodríguez MC., Gurrola GB., Possani LD. 2013. Enhanced antimicrobial activity of novel synthetic peptides derived from vejovine and hadrurin. Biochimica et Biophysica Acta 1830:3427-36. DOI: 10.1016/j.bbagen.2013.01.028.

Singh AP., Prabha V., Rishi P. 2013. Value Addition in the Efficacy of Conventional Antibiotics by Nisin against Salmonella. PLoS ONE 8. DOI: 10.1371/journal.pone.0076844.

Soren O., Brinch KS., Patel D., Liu Y., Liu A., Coates A., Hu Y. 2015. Antimicrobial peptide novicidin synergizes with rifampin, ceftriaxone, and ceftazidime against antibiotic-resistant Enterobacteriaceae in vitro. Antimicrobial Agents and Chemotherapy 59:6233-6240. DOI: 10.1128/AAC.01245-15.

Subbalakshmi C., Sitaran N. 1998. Mechanism of Antimicrobial Action of Indolicin. Microbiology Letters. 160:91-96.

Tanida T., Okamoto T., Ueta E., Yamamoto T., Osaki T. 2006. Antimicrobial peptides enhance the candidacidal activity of antifungal drugs by promoting the efflux of ATP from Candida cells. Journal of Antimicrobial Chemotherapy 57:94-103. DOI: 10.1093/jac/dki402.

Tong Z., Zhang Y., Ling J., Ma J., Huang L., Zhang L. 2014. An in vitro study on the effects of nisin on the antibacterial activities of 18 antibiotics against Enterococcus faecalis. PLoS ONE 9. DOI: 10.1371/journal.pone.0089209.

Torcato IM., Huang Y-H., Franquelim HG., Gaspar D., Craik DJ., Castanho M a RB., Troeira Henriques S. 2013. Design and characterization of novel antimicrobial peptides, R-BP100 and RW-BP100, with activity against Gram-negative and Gram-positive bacteria. Biochimica et Biophysica Acta 1828:944-55. DOI: 10.1016/j.bbamem.2012.12.002.

Xi D., Teng D., Wang X., Mao R., Yang Y., Xiang W., Wang J. 2013. Design, expression and characterization of the hybrid antimicrobial peptide LHP7, connected by a flexible linker, against Staphylococcus and Streptococcus. Process Biochemistry 48:453-461. DOI: 10.1016/j.procbio.2013.01.008.

Yeaman MR., Yount NY. 2003. Mechanisms of antimicrobial peptide action and resistance. Pharmacological Reviews 55:27-55. DOI: 10.1124/pr.55.1.2.

Zhou L., Ma X., Gao W., Yao K-H., Shen A-D., Yu S-J., Yang Y-H. 2012. Molecular characteristics of erythromycin-resistant Streptococcus pneumoniae from pediatric patients younger than five years in Beijing, 2010. BMC Microbiology 12:228. DOI: 10.1186/14712180-12-228. 

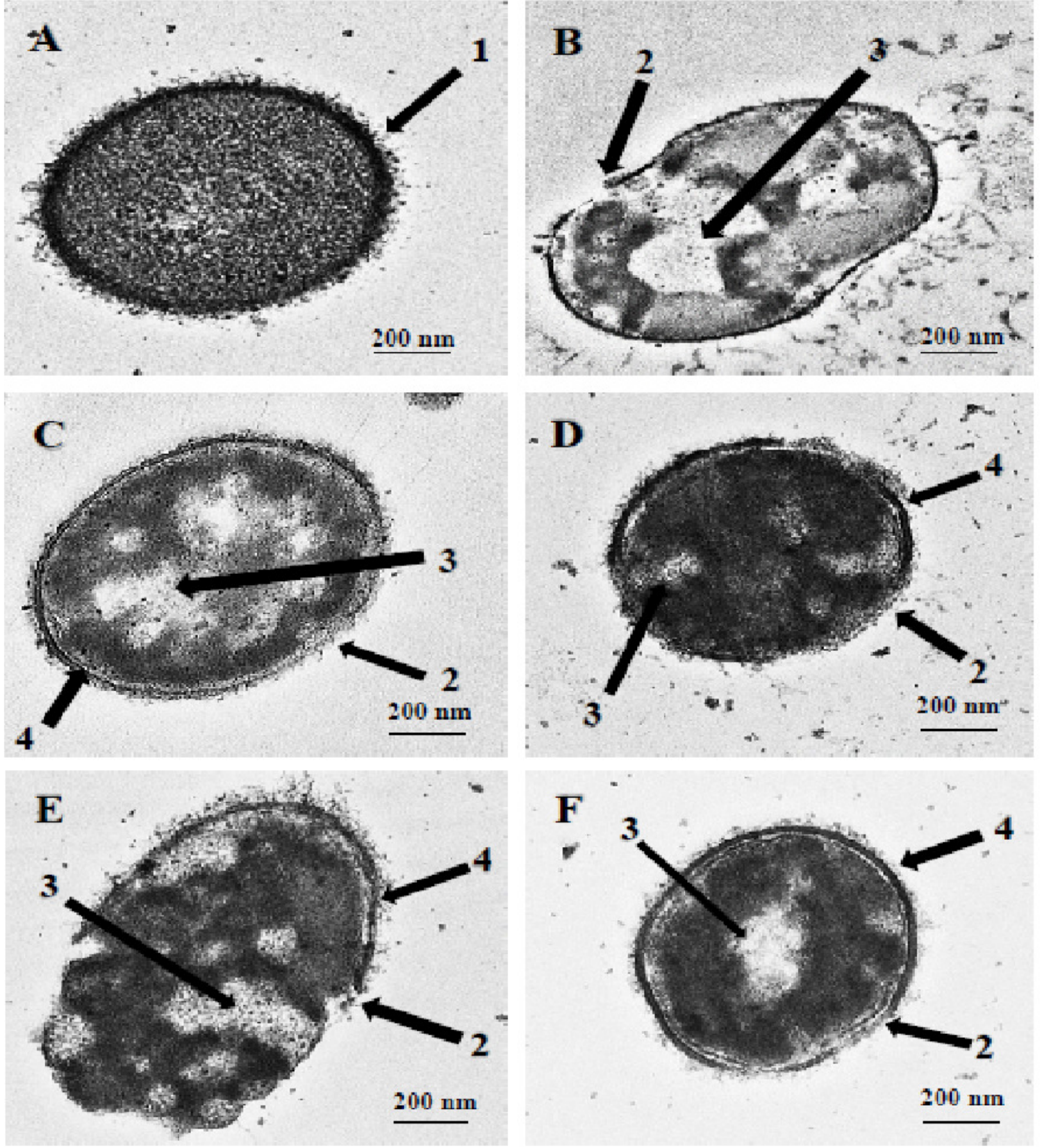

Fig 1. Transmission electron micrographs of $S$. pneumoniae after treatment with hybrid (C) RN7-IN9, (D) RN7-IN8, (E) RN7-IN7 and (F) RN7-IN6. (Arrow 2) Breakage and loss of cell 
767 wall/membrane fragments. (Arrow 3) Leakage of cytoplasm and halos formation. (Arrow 4)

768 detachment of cytoplasmic membrane from pneumococcal cell wall. Bar indicates $200 \mathrm{~nm}$.
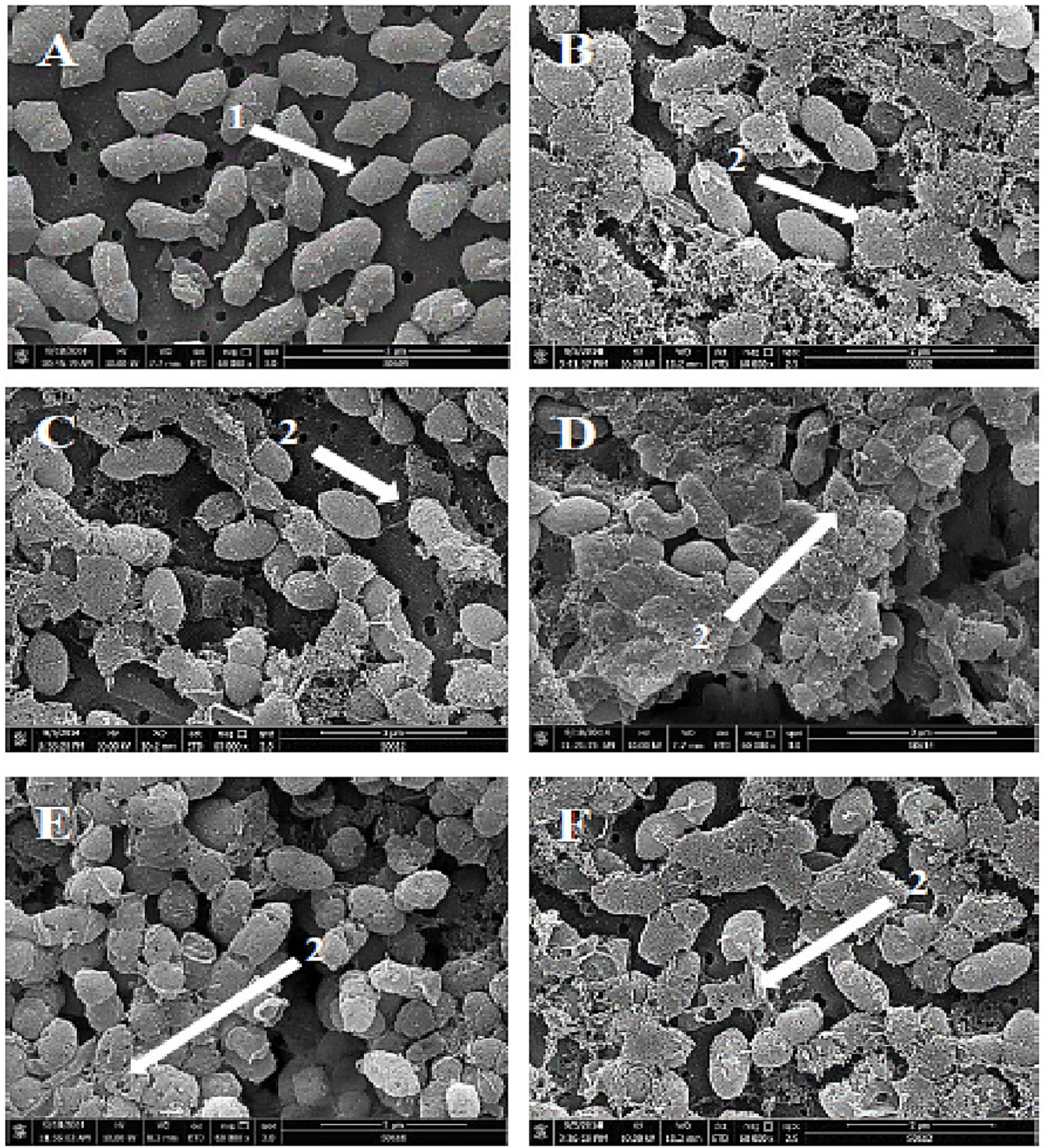

771 Fig 2. Scanning electron micrographs of $\boldsymbol{S}$. pneumoniae after treatment with hybrid peptides.

772 (A) Control cells without treatment appeared with normal shape and smooth surface (arrow 1). Fig

$773 \mathrm{~B}-\mathrm{F}$ show the severe morphological changes and surface disruption (arrow 2) of pneumococcal 
774 cells following $1 \mathrm{hr}$ incubation in presence of (B) RN7-IN10, (C) RN7-IN9, (D) RN7-IN8, (E) 775 RN7-IN7, and (F) RN7-IN6. Bar indicates $2 \mu \mathrm{m}$. 


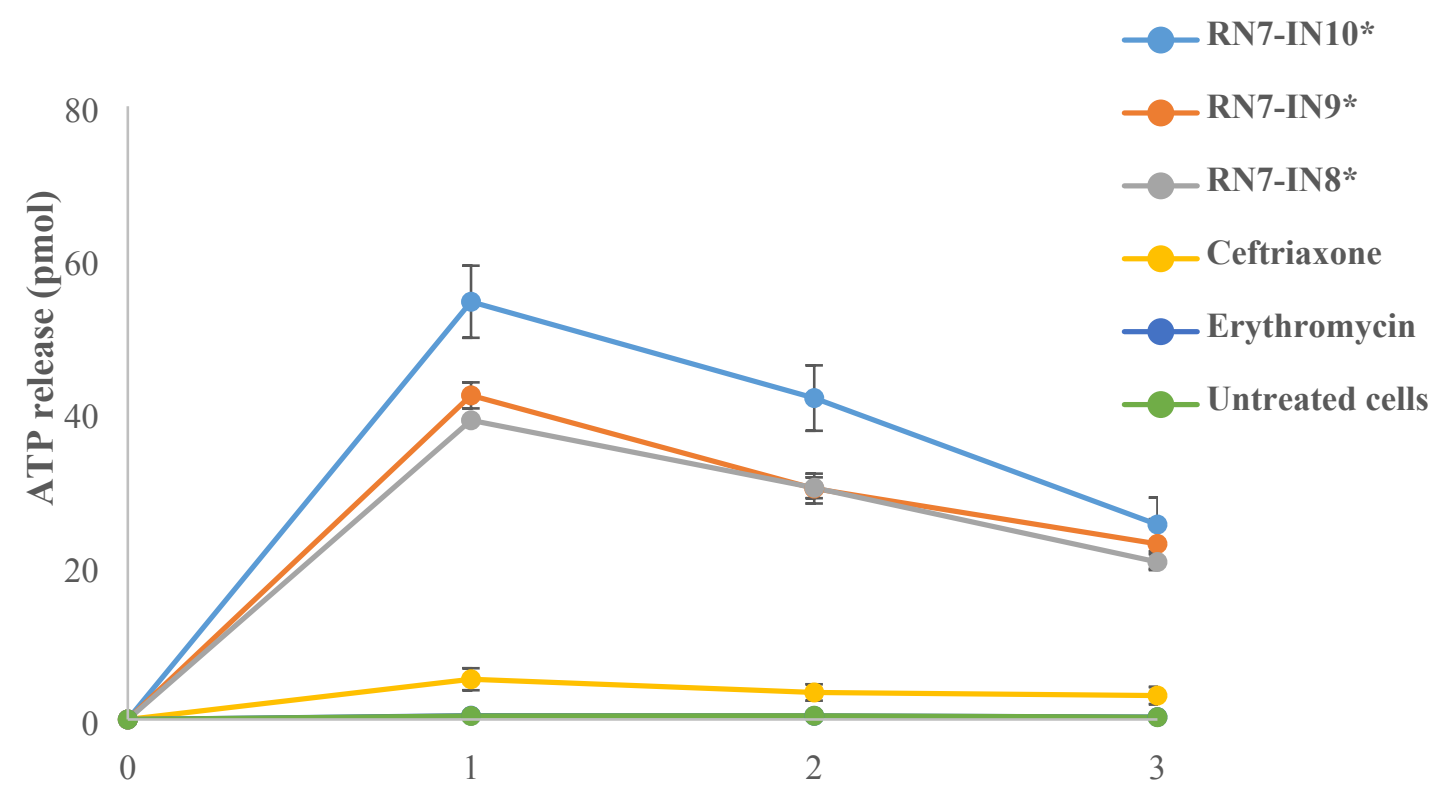

Time (hr)

776

A

777 B

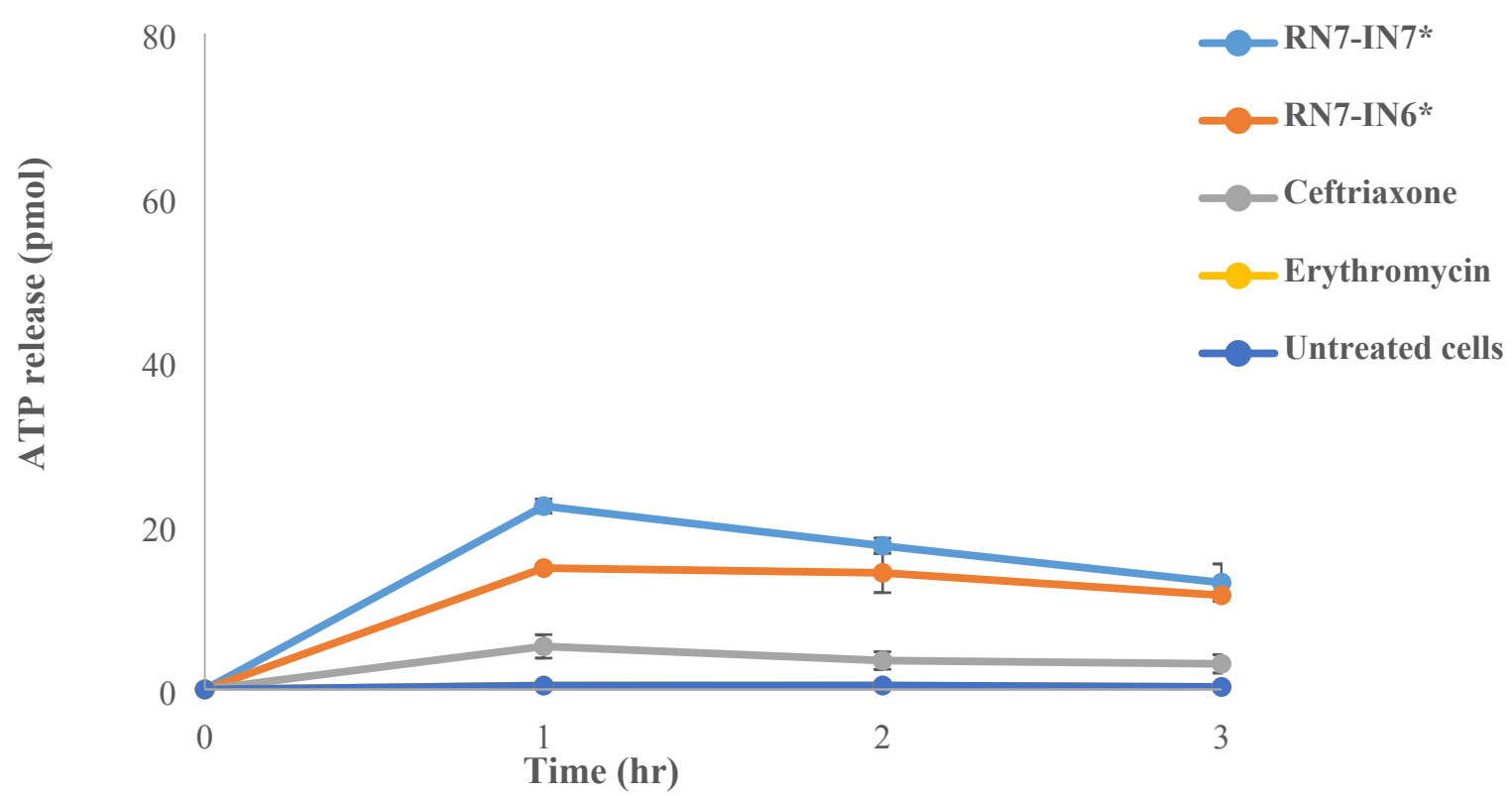

779 Fig 3. The influence of peptides on ATP release.. Two-way ANOVA with Bonferroni post-test was used to perform the statistical analysis. An asterisk (*) adjacent to peptide name directs statistical significance $(\mathrm{P}<0.001)$. Fig 3A shows the amount of ATP released upon treatment with RN7-IN10, RN7-IN9 and RN7IN8. Fig 3B shows the amount of ATP released upon treatment with RN7-IN7 and RN7-IN6. The 
783 experiment was done in triplicate. All Hybrid peptides presented stronger ATP efflux activity $(\mathrm{P}<0.001)$

784 in comparison with the standard drugs erythromycin $(\mathrm{P}>0.05)$ and ceftriaxone $(\mathrm{P}>0.05)$. 

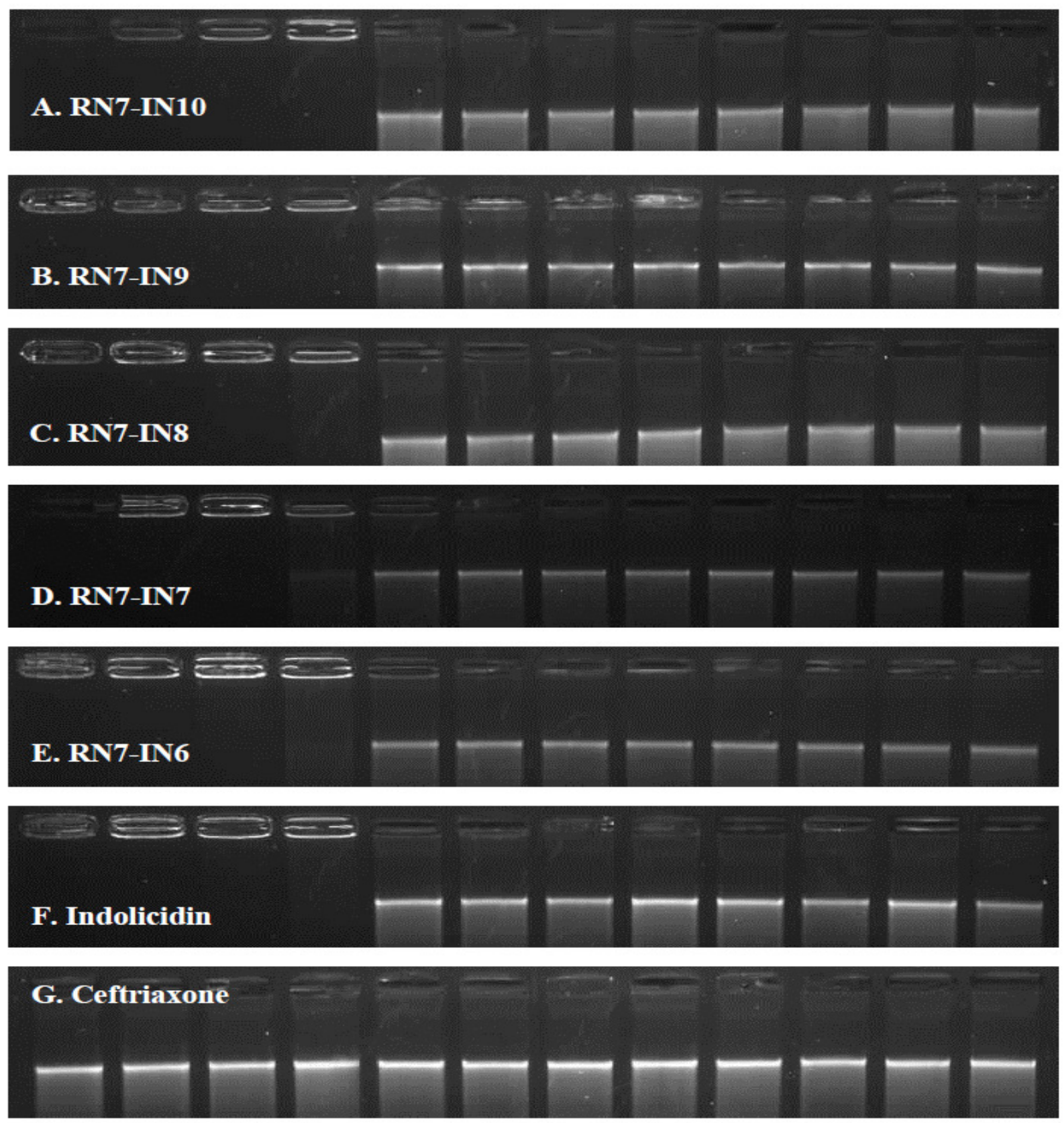

\section{H. Erythromycin}

Fig 4. The influence of the hybrid peptides on the migration of $S$. pneumoniae genomic DNA through the agarose gel. Genomic DNA (250 ng) was mixed with peptides at different concentrations 
791 erythromycin and ceftriaxone were used as negative controls. All the hybrid peptides and their parent 792 indolicidin were able to inhibit the migration of DNA at $62.5 \mu \mathrm{g} / \mathrm{ml}$.

793

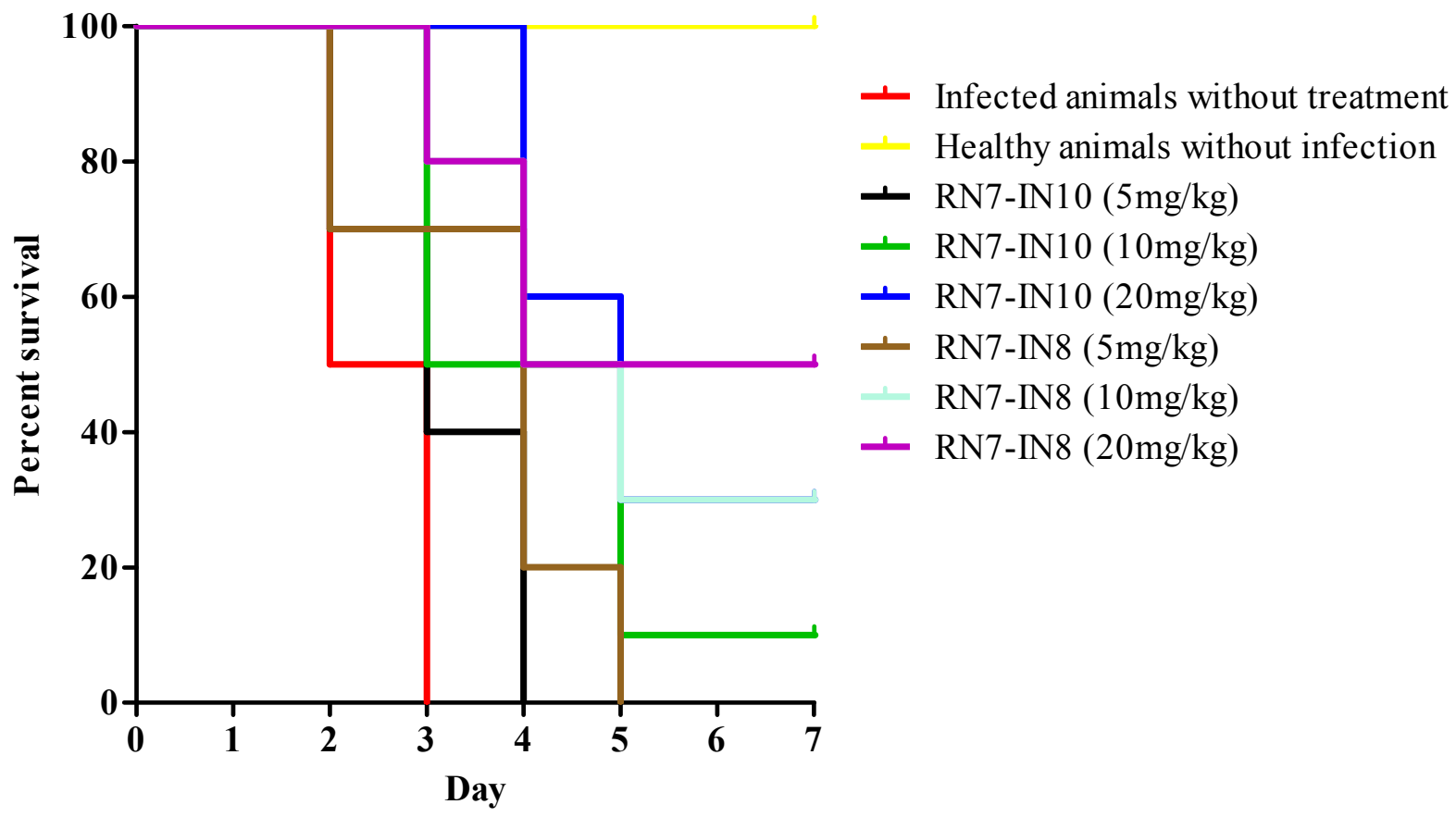

794

795

796

797

798

799

800

801

802

803

804

805

806

807

808

809
Fig 5. Survival curve of infected mice treated with RN7-IN10 and RN7-IN8. Kaplan-Meier with log-rank test (Mantel-Cox) was used to perform the statistical for all treated groups and the untreated control using. Treatment with RN7-IN8 at 20mg/kg displayed the highest survival rate of $50 \%$ up to 7 days post-infection $(\mathrm{p}<0.001)$. 


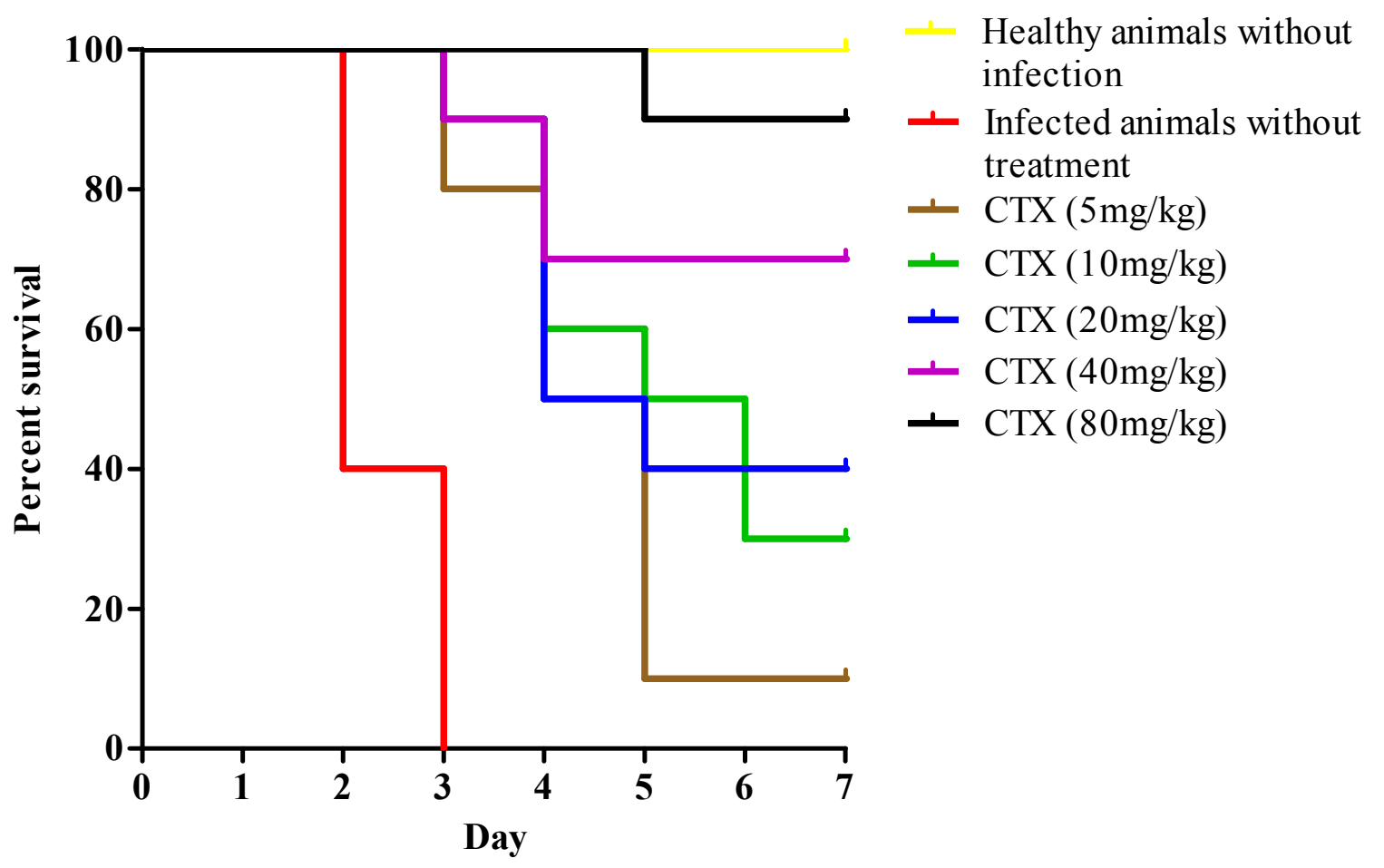

813

814 Fig 6. Survival curve of infected mice treated with ceftriaxone (CTX). Kaplan-Meier with log815 rank test (Mantel-Cox) was used to perform the statistical analysis for all treated group and the 816 untreated control. 
831

832

833

834

835

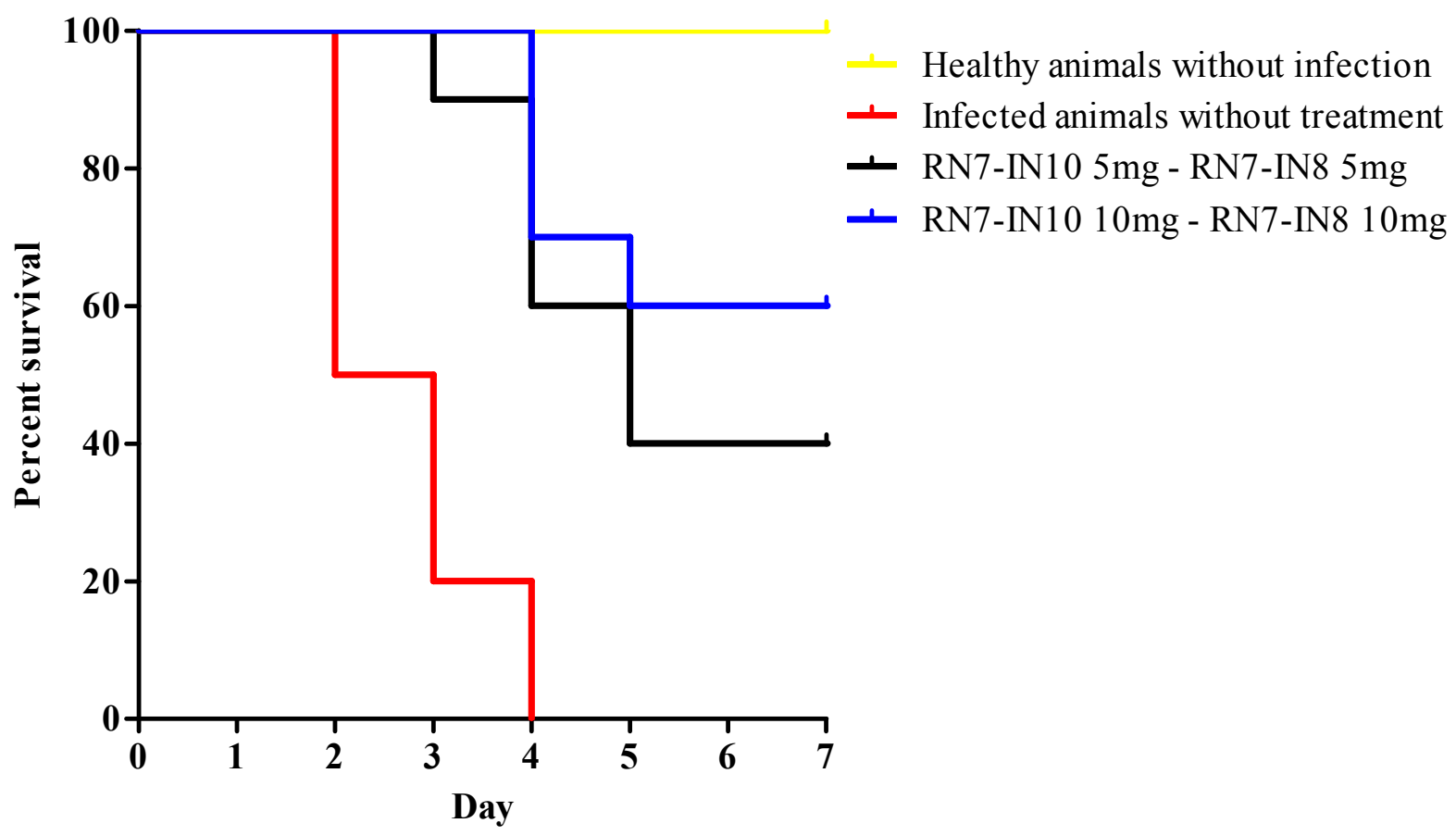

836

837

838

839

840

841

842

843

844

845

846

847

848

849

850

851

852

853

854

855

Fig 7. Survival curve of infected mice treated with combinations of RN7-IN10 and RN7-IN8. Kaplan-Meier with log-rank test (Mantel-Cox) was used to perform the statistical analysis for all treated group versus the untreated control. 


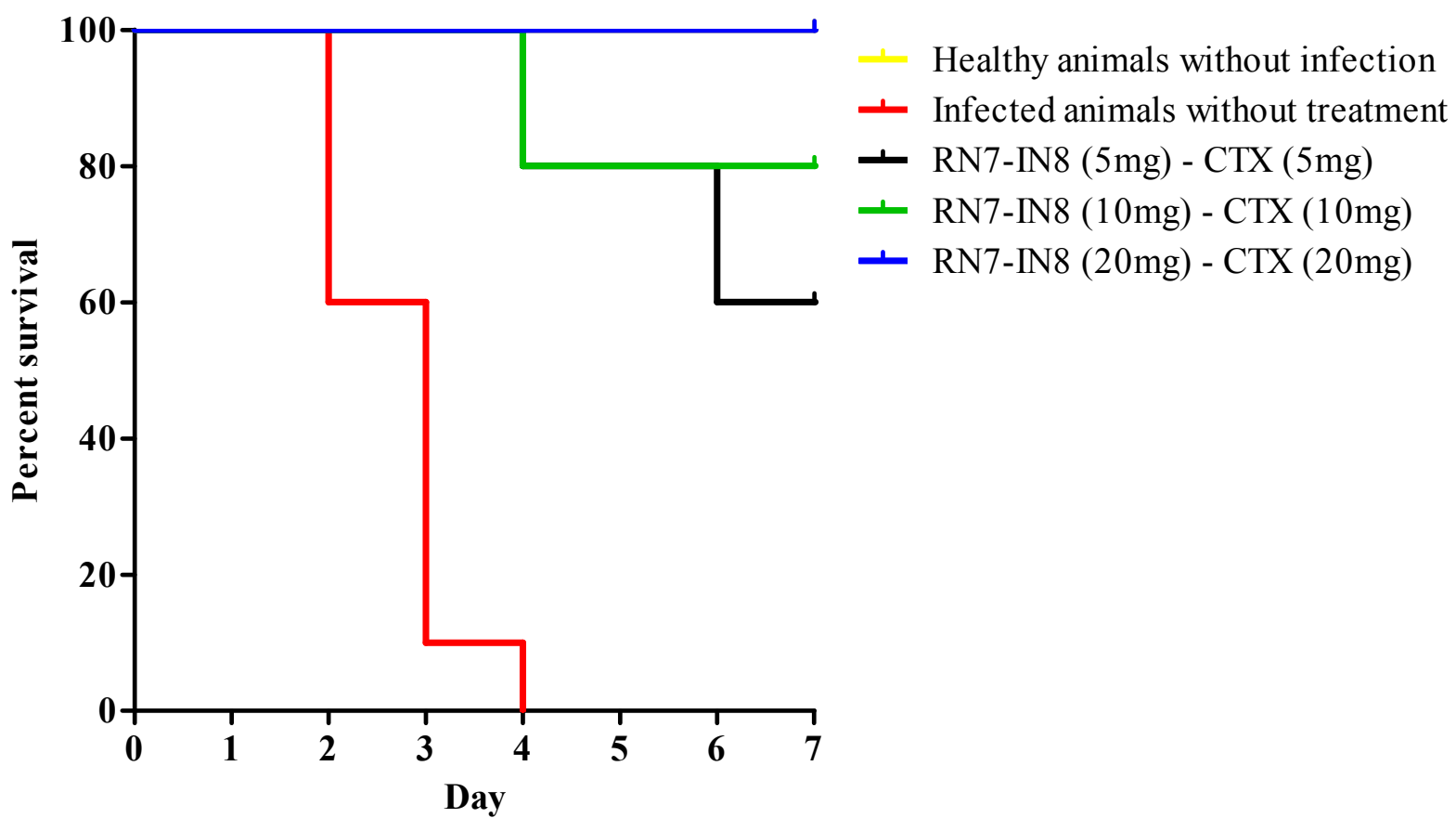

861

862

863

864

865

866

867

868

869

870

871

872

873

874

875

876

877

878

879

880
Fig 8. Survival curve of infected mice treated with combinations of RN7-IN8 and ceftriaxone (CTX). Kaplan-Meier with log-rank test (Mantel-Cox) was used to perform the statistical analysis for all treated group and the untreated control. Combination of RN7-IN and ceftriaxone at $(20 \mathrm{mg} / \mathrm{kg}-20 \mathrm{mg} / \mathrm{kg})$ showed $100 \%$ survival $(\mathrm{P}<0.0001)$. 
881

882

883

884
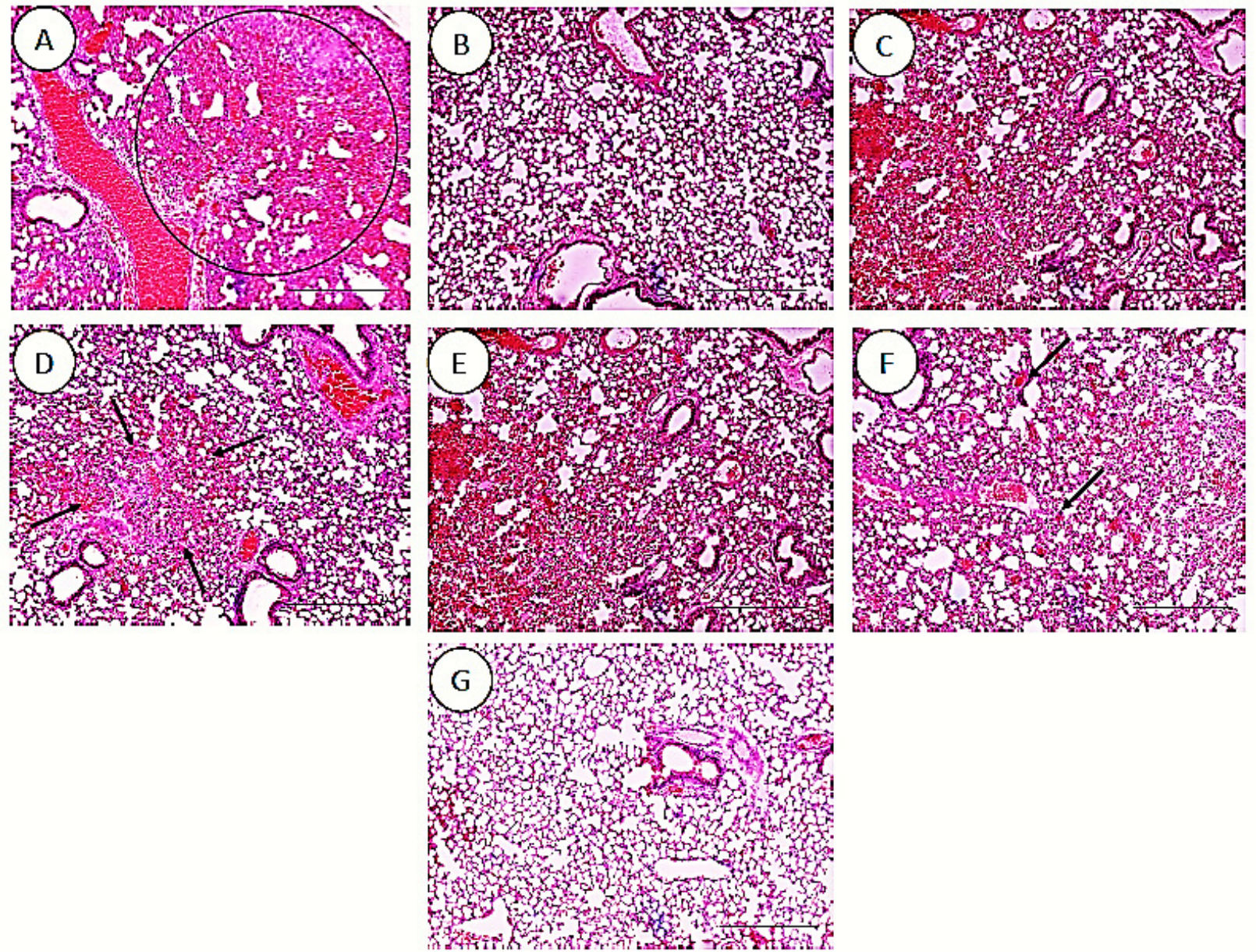

885

886

Fig 9. Histology of lungs harvested from mice infected with $S$. pneumoniae receiving treatments. (A) infected mice, (B) uninfected mice (control), (C) mice treated with RN7-IN8 (20mg/kg), (D) mice treated with combination of RN7-IN10 and RN7-IN8 (10 mg/kg + 10mg/kg), (E) mice treated with combination of RN7-IN8 and CTX $(5 \mathrm{mg} / \mathrm{kg}+5 \mathrm{mg} / \mathrm{kg})$, (F) mice treated with combination of RN7-IN8 and CTX $(10 \mathrm{mg} / \mathrm{kg}+10 \mathrm{mg} / \mathrm{kg}),(\mathrm{G})$ mice treated with combination of RN7-IN8 and CTX $(20 \mathrm{mg} / \mathrm{kg}+20 \mathrm{mg} / \mathrm{kg})$. Hematoxylin and eosin stain. Bar indicates $500 \mu \mathrm{M}$. 

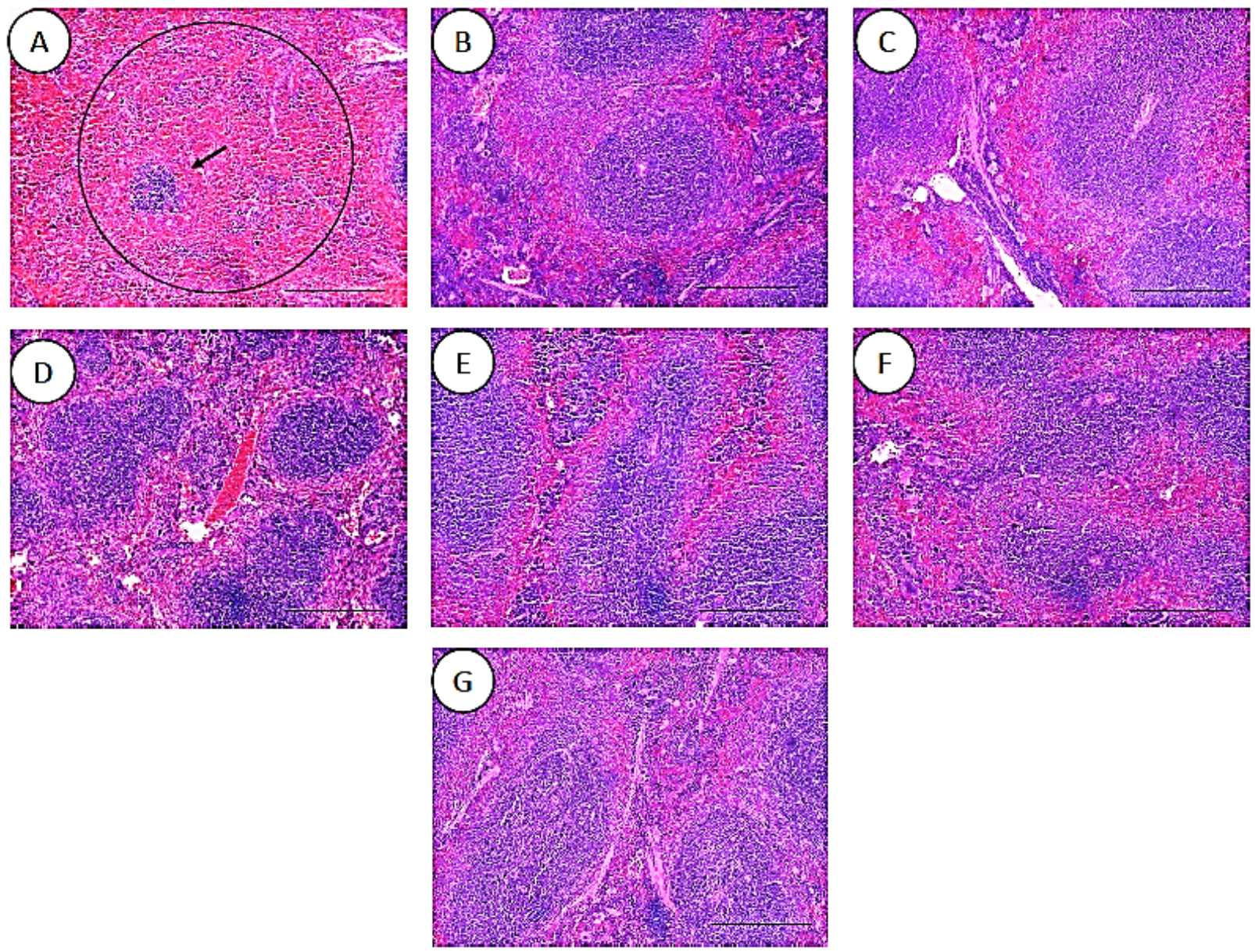

Fig 10. Histology of spleens harvested from mice infected with $S$. pneumoniae receiving treatments. (A) infected mice, (B) uninfected mice (control), (C) mice treated with RN7-IN8 $(20 \mathrm{mg} / \mathrm{kg})$, (D) mice treated with combination of RN7-IN10 and RN7-IN8 $(10 \mathrm{mg} / \mathrm{kg}+10 \mathrm{mg} / \mathrm{kg})$, (E) mice treated with combination of RN7-IN8 and CTX $(5 \mathrm{mg} / \mathrm{kg}+5 \mathrm{mg} / \mathrm{kg})$, (F) mice treated with combination of RN7-IN8 and CTX $(10 \mathrm{mg} / \mathrm{kg}+10 \mathrm{mg} / \mathrm{kg}),(\mathrm{G})$ mice treated with combination of RN7-IN8 and CTX $(20 \mathrm{mg} / \mathrm{kg}+20 \mathrm{mg} / \mathrm{kg})$. Hematoxylin and eosin stain. Bar indicates $500 \mu \mathrm{M}$. 
914 Table 1: Sequences and physicochemical properties of the template and hybrid AMPs.

\begin{tabular}{|c|c|c|c|c|c|c|}
\hline Peptide & Sequence & MIC $^{\mathbf{a}}$ & $\mathbf{a a}^{\mathbf{b}}$ & $\mathbf{M W}^{\mathbf{c}}$ & $\mathbf{Q}^{\mathbf{d}}$ & $\mathbf{P h o \%}^{\mathbf{e}}$ \\
\hline Indolicidin & ILPWKWPWWPWRR-NH2 & $15.62-31.25$ & 13 & 1907.30 & +4 & $53 \%$ \\
\hline Ranalexin & FLGGLIKIVPAMICAVTKKC-OH & 62.5 & 20 & 2105.70 & +3 & $65 \%$ \\
\hline RN7-IN10 & FLGGLIKWKWPWWPWRR-NH2 & $7.81-15.62$ & 17 & 2300.791 & +5 & $52 \%$ \\
\hline RN7-IN9 & FLGGLIKKWPWWPWRR-NH2 & $7.81-15.62$ & 16 & 2114.578 & +5 & $50 \%$ \\
\hline RN7-IN8 & FLGGLIKWPWWPWRR-NH2 & $7.81-15.62$ & 15 & 1986.408 & +4 & $53 \%$ \\
\hline RN7-IN7 & FLGGLIKPWWPWRR-NH2 & 62.5 & 14 & 1800.195 & +4 & $50 \%$ \\
\hline RN7-IN6 & FLGGLIKWWPWRR-NH2 & $7.81-15.62$ & 13 & 1709.078 & +4 & $53 \%$ \\
\hline
\end{tabular}

915

916

$917^{\mathrm{a}}$ Minimum inhibitory concentration $(\mu \mathrm{g} / \mathrm{ml})$.

$918^{\mathrm{b}}$ Number of amino acids.

$919^{\mathrm{c}}$ Molecular weight.

$920^{\mathrm{d}}$ Net charge. Lys $(\mathrm{K}), \operatorname{Arg}(\mathrm{R})$, and C-terminal amidation $\left(\mathrm{NH}_{2}\right)$ was assigned with +1 charge.

$921^{\mathrm{e}}$ hydrophobic residues $\%$.

922

923

924

925

926

927

928

929

930

931

932

933

934

935

936

937

938

939 
941 Table 2: FIC index of various combinations of hybrid peptides with each other and with standard

942 antibiotics against susceptible and resistant $S$. pneumoniae.

\begin{tabular}{|c|c|c|c|c|c|}
\hline \multicolumn{2}{|c|}{ Combination } & \multicolumn{2}{|c|}{ Susceptible $S$. pneumoniae } & \multicolumn{2}{|c|}{ Resistant S. pneumoniae } \\
\hline Drug A & Drug B & FIC index ${ }^{a}$ & Interpretation & FIC index ${ }^{a}$ & Interpretation \\
\hline \multirow[t]{6}{*}{ RN7-IN10 } & RN7-IN9 & 0.50 & Synergism & 0.37 & Synergism \\
\hline & RN7-IN8 & 0.28 & Synergism & 0.28 & Synergism \\
\hline & RN7-IN7 & 0.37 & Synergism & 0.50 & Synergism \\
\hline & RN7-IN6 & 0.26 & Synergism & 0.31 & Synergism \\
\hline & Ceftriaxone & 0.37 & Synergism & 0.31 & Synergism \\
\hline & Erythromycin & 0.26 & Synergism & 0.28 & Synergism \\
\hline \multirow[t]{5}{*}{ RN7-IN9 } & RN7-IN8 & 0.37 & Synergism & 0.50 & Synergism \\
\hline & RN7-IN7 & 0.50 & Synergism & 0.50 & Synergism \\
\hline & RN7-IN6 & 0.28 & Synergism & 0.37 & Synergism \\
\hline & Ceftriaxone & 0.31 & Synergism & 0.37 & Synergism \\
\hline & Erythromycin & 0.28 & Synergism & 0.26 & Synergism \\
\hline \multirow[t]{4}{*}{ RN7-IN8 } & RN7-IN7 & 0.50 & Synergism & 0.50 & Synergism \\
\hline & RN7-IN6 & 0.31 & Synergism & 0.37 & Synergism \\
\hline & Ceftriaxone & 0.31 & Synergism & 0.37 & Synergism \\
\hline & Erythromycin & 0.28 & Synergism & 0.26 & Synergism \\
\hline \multirow[t]{3}{*}{ RN7-IN7 } & RN7-IN6 & 0.50 & Synergism & 0.50 & Synergism \\
\hline & Ceftriaxone & 0.50 & Synergism & 0.50 & Synergism \\
\hline & Erythromycin & 0.37 & Synergism & 0.37 & Synergism \\
\hline \multirow[t]{2}{*}{ RN7-IN6 } & Ceftriaxone & 0.37 & Synergism & 0.31 & Synergism \\
\hline & Erythromycin & 0.28 & Synergism & 0.28 & Synergism \\
\hline
\end{tabular}

${ }^{a}$ FIC index $\leq 0.5$ represents synergy; $>0.5-\leq 4.0$ represents indifference; $>4.0$ represents antagonism.

Highlighted in bold: peptide-antibiotic combination with synergistic effect.

945 